\title{
The Monitoring and Advisory Functions of Corporate Boards: Theory and Evidence
}

Article in SSRN Electronic Journal · August 2008

DOI: $10.2139 /$ ssrn. 1327066

CITATIONS

18

1 author:

Dong Chen

University of Baltimore

17 PUBLICATIONS 80 CITATIONS

SEE PROFILE
READS

40

All content following this page was uploaded by Dong Chen on 17 June 2014. 


\title{
The Monitoring and Advisory Functions of Corporate Boards: Theory and Evidence*
}

\author{
Dong Chen $^{\dagger}$
}

August 1, 2008

\begin{abstract}
I develop and test a model of the two primary functions of the board of directors of a public corporation: monitoring and advising management. The model shows that higher advising intensity is associated with lower monitoring quality and higher agency costs. To test the model, I use the number of independent directors who are at the same time executive board members of other corporations as an empirical proxy for the board's advising intensity. I test and find evidence for the validity of this empirical proxy, by contrasting the corporate policies independent executives (IEs) choose for their own firms with those they advocate as outside directors. Consistent with the predictions of the model, I find that IEs are associated with proxies for higher agency costs. I also find that IEs are positively, significantly, and causally associated with firm performance. Finally, I argue that the significant relation between IEs and firm performance is due to the scarcity of IEs, and use the passage of Sarbanes-Oxley Act as a natural experiment to demonstrate the validity of this argument.
\end{abstract}

\footnotetext{
*I thank Alon Brav, David Hsieh, Ron Kaniel, Manju Puri, Adriano Rampini, S. "Vish" Viswanathan, and especially Michael Bradley, Simon Gervais, John Graham, Rich Mathews, and David Robinson for helpful comments and suggestions, Frank Ecker for providing the Eloadings data, Andrew Metrick for providing the G-Index data with CRSP PERMNO, and Kathleen Farrell for advising me on the director compensation data. All the remaining errors are my own.

${ }^{\dagger}$ Department of Economics, Finance, and Management Science, University of Baltimore, Baltimore, MD 21201. Phone: (410)837-4919. Email: dchen@ubalt.edu.
} 
“...In short, we cannot describe the job we have given a modern corporate board without using such terms as paradox, conflict, contradiction, and oxymoron..."-Ralph D. Ward Saving the Corporate Board-Why Boards Fail and How to Fix Them

\section{Introduction}

Monitoring and advising management are the two primary functions of corporate boards of directors (Monks and Minow (2004)). The monitoring function requires the board to play a "watchdog" role in order to align the incentives of the management with the interests of the shareholders. In the advisory function, however, the board takes a more hands-off approach regarding monitoring and uses the expertise of its members to counsel management in establishing corporate strategies and policies.

The monitoring function has been featured prominently in both the popular press and academic literature, especially after the passage of the Sarbanes-Oxley Act (SOX) and the new exchange listing standards. Hermalin and Weisbach (2003) review the economic literature on corporate boards and conclude that boards, in particular independent directors, are generally effective in the traditional monitoring function, such as decisions regarding CEO succession and CEO compensation, but are generally uncorrelated with firm performance. ${ }^{1}$ In contrast, the board's advisory function, though considered very important in the popular press, has received far less attention in the academic literature. Financial economists only recently have begun to consider the advisory role of the board, and how it impacts the monitoring role. ${ }^{2}$

This paper develops a theoretical model to analyze the tradeoff between the monitoring and advisory functions of the board, and makes the first attempt to test this tradeoff empirically. I first derive a simple model incorporating the two functions. In the model the board chooses whether to

\footnotetext{
${ }^{1}$ Independent directors are the directors who are not affiliated with the firm except for their directorships. The literature generally uses the proportion of independent directors to board size to proxy for the monitoring intensity of the board, and to study its relation with firm performance.

${ }^{2}$ For the discussion of boards' advisory role in the popular press, see Mace (1986), Lorsch and MacIver (1989), Ezzamel and Watson (1997), PricewaterhouseCoopers (2001), Carter and Lorsch (2004), and Ward (2003) as quoted above. For recent academic research on the advisory role, see Booth and Deli (1999), Agrawal and Knoeber (2001), Song and Thakor (2006), Coles, Daniel, and Naveen (2006), Güner, Malmendier, and Tate (2007), and Graham, Hazarika, and Narasimhan (2007). For theoretical work on both roles and their potential conflict, see Adams and Ferreira (2007) and Harris and Raviv (2007).
} 
advise the CEO and whether or not to replace the incumbent CEO by inferring his ability from the firm's profit realization. The board is assumed to have the same utility function as the shareholders, and has the incentive to make the right replacement decision since such a decision affects firm value. ${ }^{3}$ The $\mathrm{CEO}$ in the model takes an unobservable action that increases his utility at the expense of shareholders. I interpret the reduction of firm value that comes with such actions as agency costs. Importantly, the CEO benefits from imposing these costs on the firm only if he can retain his job. If the board does not advise the CEO, realized profit will equal the CEO's ability net of agency costs. Similar to Holmström (1999), the CEO's career concern motivates him not to choose the action that results in the maximum level of agency costs, in an effort to make the board infer a higher ability and to reduce the probability of replacing him, though in equilibrium such ability is perfectly revealed. If the board does advise the CEO, the firm's profit will equal the board's ability net of agency costs, hence making it impossible for the board to infer his ability. Without career concerns, the CEO always chooses the action that generates the maximum level of agency costs. The model thus predicts that when the board advises, the quality of the replacement decision is lower and agency costs are higher. As a result, the model further predicts that unless its ability is sufficiently high to overcome such costs, it is not optimal for the board to advise.

To empirically test the model I focus on independent directors because they are the directors who are more likely to possess both functions. In contrast, inside directors and grey directors generally are not expected to play much of a monitoring role since they are the party or are directly affiliated with the party being monitored. ${ }^{4}$ Focusing on independent directors also enables me to reevaluate the findings in the vast literature on independent directors, which only considers their monitoring function, and study the implications of recent regulations that impose higher requirements for the proportion of independent directors. ${ }^{5}$

\footnotetext{
${ }^{3}$ As a recent example of such decision affecting firm value, Merrill Lynch's stock price jumped $8.5 \%$ upon circulation of the rumor to fire the CEO Stanley O'Neal.

${ }^{4}$ Inside directors are the directors who are employees of the firm, such as CEO, CFO, etc., also called executive board members. Grey directors are the directors who are not employees but have some business relation with the firm, such as suppliers, investment bankers, etc., sometimes called affiliated or linked directors.

${ }^{5}$ SOX requires all public firms to have audit committees made up of all independent directors. Major exchanges (NYSE, NASDAQ, AMEX) further require all listed firms to have majority of the board composed of independent directors, and all independent nomination and compensation committees, if they exist. NYSE further enforces that all listed firms have those two committees.
} 
To test the model, I use the director database from Investor Responsibility Research Center (IRRC) to construct an empirical measure of the number of independent directors who are at the same time executive board members of other firms covered in the database. Indeed, Kaplan and Reishus (1990), Booth and Deli (1996), Fich (2005), and Perry and Peyer (2005) find that such directors have the expertise and incentives to advise management of the receiver firms. ${ }^{6}$ I hypothesize that independent executives (IEs) possess the required knowledge and skills to advise management. As a result of their more active advisory role, such boards are not expected to perform as well in their monitoring function, resulting in lower monitoring quality and higher agency costs. Furthermore, using IEs as the empirical proxy enables me to potentially identify their advisory function directly, by contrasting the corporate policies they choose for their own firms with those they advocate as independent directors on the receiver firms' boards.

I first test whether IEs are associated with lower monitoring quality as predicted by the model. I examine the relation between the quality of the traditional governance functions and IEs. These functions include making CEO succession decisions, setting CEO compensation, and influencing the degree of financial transparency. Consistent with the predictions of the model, I find that conditioned on other economic determinants of these governance variables, IEs are associated with lower CEO turnover and turnover-to-performance sensitivity, higher CEO compensation, larger increases in CEO compensation, lower pay-for-performance sensitivity, and lower earnings quality which proxies for the degree of financial transparency.

I then test whether IEs indeed advise management, and whether such advice benefits the firm. Kaplan and Reishus (1990) and Fich (2005) find that the probability of executives receiving outside directorships increases with the firm's performance. If performance is affected by corporate policies, it is likely that IEs would advise the receiver firm's management using insights from their own firms' policies. As a result, I expect the receiver firm's corporate policies to resemble those of the sender firm, controlling for other firm-specific determinants of such policies. ${ }^{7}$ I follow Bertrand

\footnotetext{
${ }^{6} \mathrm{~A}$ receiver firm is a firm who hires executives from other firms as independent directors. In the context of this paper, the executives are confined to those who also sit on boards as inside directors.

${ }^{7}$ A sender firm is a firm who has at least one executive board member serving as independent directors in other firms.
} 
and Schoar (2003) and test three types of corporate policies: investment policy, financial policy, and organizational strategy. Consistent with this hypothesis, I find that the correlation between the sender and receiver firm is positive for each of the ten policy variables examined. In addition, such correlation is highly significant for capital expenditure, cash holdings, dividend payout ratio, R\&D expenses and selling, general, and administrative (SG\&A) expenses, suggesting IEs might advise more intensively on these policies than others. These results provide the first direct and comprehensive evidence for the board's advisory function.

I then assess the effect that IEs have on the firm's corporate policies. I find that firms whose board include more IEs have lower capital expenditure and leverage, higher dividend payout ratio, R\&D expenses, adverting expenses, and SG\&A expenses.

To test whether the IEs' advice benefits the firm, I measure the relation between the number of IEs on the board and the firm's performance. I find IEs are positively and strongly associated with performance as proxied by Tobin's Q. Furthermore, several robustness checks suggest that such correlation is causal. In addition, the correlations of IEs with corporate polices generally have the same signs as the policies' correlations with firm performance, suggesting that on average IEs are good advisors. I also find that the positive relation between IEs and firm performance is driven by those IEs who come from firms larger than the receiver firm. If the firm size that an executive can manage serves as a proxy for his ability as argued by Rosen (1982) and documented in Hayes and Schaefer (1999), this evidence is consistent with the prediction of my model: only when IEs' abilities are high enough to overcome the associated agency costs will it be optimal for them to advise. These results are consistent with the board acting optimally in balancing the two functions on average, and that the benefit of the IEs' advising management exceeds the associated higher agency costs that they engender.

Demsetz and Lehn (1985) argue that no significant relation should be expected between a governance variable and firm value if firms behave optimally and there are no market frictions. I test whether a particular friction could potentially explain IEs' significant relation with firm performance. I use SOX and the associated change in the corporate environment as a natural experiment, 
and find that the evidence is consistent with a scarcity hypothesis in which such significant relation is due to the limited supply of qualified executives on the market for directors.

This paper makes several novel contributions to the literature on corporate governance and the policy debate regarding the role that boards of directors should play. First, it offers the first direct and comprehensive empirical evidence on the board's advisory function. By using the number of IEs on a firm's board as a proxy for its ability to advise management, I can estimate the effect of this advice on the receiver firm's corporate policies by comparing them with those of the IEs' own firms. In contrast, Agrawal and Knoeber (2001) use the presence of politically-affiliated directors and firm's demand for political connections to identify their advisory function. Similarly, Coles, Daniel, and Naveen (2006) and Graham, Hazarika, and Narasimhan (2007) use the firm's sales revenue, leverage and the number of business segments as proxies for the complexity of the firm and hence the firm's advising demand to identify outside directors' advisory function. The empirical methodology used in this paper is similar to that of Booth and Deli (1999) and Güner, Malmendier, and Tate (2007), in which they use the link between the sitting of financial experts on the board and the firm's external funding to identify their advisory function. Unlike their single variable identification strategy, using executives who are responsible for all the corporate policies as an empirical measure enables me to examine a much broader category of policies.

Second, to the best of my knowledge, this paper is also the first to argue and provide evidence that the scarcity of directors drives their significant relation with firm performance. This has important implications for our understanding of the operations of the market for directors. Most of the literature on boards of directors relies on the reputational concerns of the independent directors to align their interests with those of shareholders (Fama (1980), Fama and Jensen (1983)). Such concern should only be relevant when the market for directors operates through a demand-driven mechanism based on homogenous and unlimited supply of qualified independent directors. In light of the limited supply of such directors (see also Linck, Netter, and Yang (2007)), the means to align their interest with that of shareholders have not been explored formally in the literature, which raises an issue for future research. 
Third, this paper adds to the early stage of the theoretical work on the potential conflict between the boards' two major functions, as initiated by Adams and Ferreira (2007) and Harris and Raviv (2007). Although my model shares some similarities with these two papers by analyzing the dual role of monitoring and advising that corporate boards should play, the underlying tradeoff between the two roles is different. Adams and Ferreira (2007) and Harris and Raviv (2007) propose that the board may have to be less independent (or controlled by insiders) to induce management to reveal the private information that may improve the quality of advice. In contrast, my model predicts a lower monitoring quality as a consequence of advising management. This implies that even apparently independent directors can have lower monitoring qualities. Furthermore, in contrast to the prediction of Adams and Ferreira (2007) that the advisory function is always beneficial to the firm, my model implies that the board should not advise unless it is sufficiently skilled.

Fourth, regarding the post-SOX regulations requiring more independent directors on the board based on the assumption that they may perform a better monitoring function, I show that apparent independence may not translate into effective monitoring. Similarly, Coles, Daniel, and Naveen (2007) argue that apparently independent directors who joined the board after the CEO had assumed office are not effective monitors, since they tend to be sympathetic to the CEO. In contrast, lower monitoring quality in this paper comes from independent directors' optimal balance of the two functions. In terms of the attempt to link independent directors' monitoring quality with firm performance as in most of the literature, I show that inferior monitoring does not translate directly into worse firm performance, because superior advice may accompany weak monitoring, with a net positive effect on firm value. Conversely, my approach highlights that effective monitoring does not necessarily suggest improved firm performance. This may offer an explanation to the conclusion reached in Hermalin and Weisbach (2003), that independent directors are generally effective monitors but uncorrelated with firm performance.

Finally, this paper adds to the growing literature that seeks to evaluate the economic benefits and costs of SOX and the new exchange regulations (Grinstein and Chhaochharia (2005) and Wintoki $\underline{(2007)}$, among others). I show that regulations that force firms to include more independent direc- 
tors on their boards may have backfired by simultaneously reducing the supply of such directors. ${ }^{8}$ To make matters worse, executives in large firms have become more reluctant to join the boards of other firms, as the legal liability and time commitment that now come with board membership have increased considerably since SOX. This resulted in a dramatic shift of the demographics of IEs: pre-SOX executives sat on slightly smaller firms as IEs on average, while post-SOX the trend is dramatically reversed. As a consequence, the association between IEs from larger firms and receiver firm's performance is stronger post-SOX. This evidence is most consistent with firms preferring executives from larger- or similar-sized firms, and when the firms were unable to keep the preferred IEs the average size of all IEs' sender firms shrank dramatically. This reduced talent pool imposes a cost for the firms desiring the service of IEs, a cost that has yet to be explored in the literature.

The remainder of the paper is arranged as follows. Section 2 models the tradeoff between the monitoring and advisory functions of the board. Section 3 describes the data and proxies used in the empirical tests, and provides the summary statistics. Section 4 examines IEs' monitoring function. Section 5 examines IEs' advisory function. Section 6 examines the relation between IEs and firm performance. Section 7 uses SOX to test several competing hypotheses to explain the significant relation between IEs and firm performance. Section 8 examines the robustness of the results. Finally, Section 9 concludes.

\section{The Model}

I consider a simple one-period model. The shareholders of a firm elect a board to represent their interests. For simplicity, the board is assumed to have the same preferences as the shareholders. ${ }^{9}$ A CEO is hired by the board to run the firm. Both the board and the CEO are assumed to be riskneutral. The CEO's primary job is to choose the corporate policy that maximizes firm value. His ability to do so is initially unknown to both the board and the CEO, as in Holmström (1999), but is

\footnotetext{
${ }^{8}$ See Lucchetti and Langley (2007) for a recent related article in Wall Street Journal about the thin talent pool for top jobs in financial firms, due to firms' eagerness to fire executives based on short-term performance.

${ }^{9}$ For example, the alignment of the incentives between the board and the shareholders could be achieved via stock compensation.
} 
known to have a prior distribution $a \sim N\left(a_{0}, \sigma_{a}^{2}\right)$. As in Jensen and Meckling (1976), the CEO's interests may not be completely aligned with those of the shareholders, and he may conduct some activities that are beneficial to himself at the expense of shareholders. Such activities may include empire building, setting excessive corporate perquisites, and so on. I assume that such an action reduces the firm's value by $C$ and increases the CEO's utility by $2 C$. I assume that the action is taken today but the benefit can only be enjoyed in the future, if the CEO retains his job. In effect, $C$ can be interpreted as an agency cost for the firm. Since the CEO's action is unobservable, the value of $C$ cannot be contracted upon. However, in equilibrium, by solving the CEO's optimization problem the board can infer $C$ with certainty.

The profit of the firm is assumed to be the difference between the CEO's ability and the agency cost:

$$
\pi=a-C
$$

The CEO's utility is assumed to be

$$
\begin{aligned}
U_{c} & =\alpha \pi+\Theta 2 C \\
& =\alpha a+(2 \Theta-\alpha) C
\end{aligned}
$$

where $0 \leq \alpha<1$ is a proxy for the degree of the alignment between shareholders and the CEO's interests, ${ }^{10}$ and

$$
\Theta= \begin{cases}1 & \text { if the CEO keeps his job at the end of the period } \\ 0 & \text { if the CEO is replaced at the end of the period }\end{cases}
$$

This utility function implies that without any concern for job security $(\Theta=1)$, the CEO would always choose the maximum level of agency cost. I assume $0 \leq C \leq \bar{C}$. The upper bound for $C(\bar{C})$ can be interpreted as the point at which litigation risk and other unmodelled costs reach excessive levels for the CEO. To ensure that the expected profit is always positive, I assume that $a_{0}>\bar{C}$.

The board has two functions: monitoring and advising the CEO. I assume the board always monitors the CEO but can choose whether or not to advise him. Monitoring is manifested through

\footnotetext{
${ }^{10}$ Such alignment could be in the form of shareholdings, option awards, long term incentive payments, etc.
} 
the board's replacement decision regarding the CEO by inferring his ability based on the profit realization, and the effect their decision has on the CEO's choice of the agency cost.

Advising the CEO may include activities such as suggesting a new investment project, proposing to increase cash holdings, and so on. I assume that the quality of the advice depends on the board's ability, which is initially unknown to both the CEO and the board, and has a prior distribution $b \sim N\left(b_{0}, \sigma_{b}^{2}\right)$. I assume $a$ and $b$ are independent so the board cannot infer $a$ through $b$. I also assume that if the board advises the CEO, the profit is its own ability net of the agency cost: ${ }^{11}$

$$
\pi=b-C
$$

Acting in the best interest of shareholders, the board is assumed to maximize expected profits by choosing whether or not to advise the CEO and deciding whether the incumbent CEO needs to be replaced by a new one, whose ability $a^{\prime}$ is independent from $a$, but is drawn from the same prior distribution $a^{\prime} \sim N\left(a_{0}, \sigma_{a}^{2}\right)$. I assume that if the board does not make the right replacement decision, the firm profit suffers an additional loss resulting from either a less capable incumbent CEO running the firm or a more capable one being fired pre-maturely. The board's utility function is assumed to be

$$
U_{b}=\pi-\Lambda P
$$

where $\Lambda$ is a dummy variable defined as

$$
\Lambda= \begin{cases}1 & \text { if the board does not make the right replacement decision } \\ 0 & \text { if the board makes the right replacement decision. }\end{cases}
$$

$P>0$ is the value lost due to future managerial incompetence. This assumption eliminates the uninteresting case in which the board commits to fire the incumbent CEO regardless of its ex-post assessment of his ability, as such commitment perfectly aligns the CEO's interest with that of the shareholders. In the event that the incumbent CEO's posterior ability is the same as a replacement's

\footnotetext{
${ }^{11}$ This assumption makes the profit dependent on the board's own ability and the agency cost, not on the CEO's ability. In general, as long as the quality of the replacement decision increases with the precision of the board's inference of the CEO's ability as in a dynamic setting (unlike the model's one period setting), and the board's advice influences the decision making and hence decreases such precision, the conclusions will be similar.
} 
prior ability, I assume that the board keeps the incumbent CEO. I also assume that if the board is indifferent between advising or not, it will choose to advise.

The timeline of the model is as follows:

- Shareholders choose advisory intensity $\theta$;

- The CEO takes a hidden action that results in reduction of firm value by $\mathrm{C}$;

- Profit $\pi$ is realized;

- The board makes the replacement decision for the incumbent CEO;

- At the end of the period the firm is liquidated and proceeds are distributed accordingly.

Since the prior distribution of $a$ is symmetric around $a_{0}$, the probability that the CEO gets fired is $\frac{1}{2}$. This means that the expected value of $\Theta$ is $\frac{1}{2}$ and the expected value of $2 \Theta-\alpha$ is positive. Hence, the assumption that the CEO gains $2 C$ (rather than simply $C$ ) from choosing $C$ implies that the CEO always prefers setting $C$ equal to $\bar{C}$ when his choice does not affect any of the board's decisions. Because the effect of $C$ on the board's decision is the focus of this model, this assumption simplifies the the analysis further by assuming away the (uninteresting) case that simple incentive alignment is sufficient to induce the CEO to choose a lower level of agency cost.

To ensure that the board has to balance between the monitoring and advisory functions, the agency cost has to be sufficiently high. I make the following assumption regarding the maximum level of the agency $\operatorname{cost} \bar{C}$ :

$$
\bar{C}>\frac{(1-\alpha) \sigma_{a}}{2 \phi(0)},
$$

where $\phi($.$) is the pdf of standard normal distribution. This technical assumption guarantees that$ there is an interior solution for $C$ in the CEO's optimization problem.

I use backward induction to solve the model. All the formal proofs are in the Appendix. It is clear that the board cannot infer the CEO's ability a under the advisory-scenario, since the profit $\pi$ is not dependent on $a$, hence the incumbent CEO is always retained by assumption. This also suggests that the sensitivity of turnover to performance is zero. In contrast, the board can infer $a$ if it does not advise, since $\pi$ then depends on both $a$ and $C$. In equilibrium the board will know $C$ and hence $a$ with certainty by observing $\pi$ and solving the CEO's optimization problem. Therefore 
there is a possibility for the CEO to be replaced, and the replacement decision depends on $\pi$. As a result, the sensitivity of turnover to performance is positive.

Proposition 1. The incumbent CEO is less likely to be replaced, and the turnover-to-performance sensitivity is lower, if the board advises him.

Since the CEO's job is secure under the board's advisory scenario, he will always choose the maximum level of the agency cost $\bar{C}$. If the board does not advise, career concerns motivate him not to choose too high a $C$ in an effort to convince the board to retain him through higher values of $\pi$. In equilibrium, however, the board learns $C$ and $a$ perfectly. But the CEO is "trapped" to this level of $C$ as any other choice of $C$ will negatively bias the board's assessment of his ability.

Proposition 2. The agency cost $C$ is higher if the board advises the CEO.

Since the board acts in the best interests of shareholders, it will choose whether or not to advise by balancing the higher agency cost associated with advising, against the benefit from its potentially higher ability. The board will thus choose the advisory function only if such benefit is sufficiently high to overcome the cost. This is formally established in Proposition 3.

Proposition 3. It is not optimal for the board to advise the CEO unless

$$
b_{0}-a_{0} \geq \bar{C}-\frac{(1-\alpha) \sigma_{a}}{2 \phi(0)}>0
$$

The key to test the model is to identify the type of boards that are more likely to play the advisory function than other boards. Because boards consist of more than one decision-maker, it is expected that boards play more of an advisory role when they include more members who are qualified to advise management.

\section{Data and Summary Statistics}

This section describes the data and proxies used in the empirical analysis to test the model above, and reports the summary statistics for the key variables. 


\subsection{Data and Empirical Proxies}

The data for directors are taken from IRRC, covering mostly S\&P 500, S\&P MidCap 400 and S\&P SmallCap 600 between 1996 and 2005. ${ }^{12}$ For each firm in a given year, IRRC lists the information for each director such as its type (inside director, grey director, or independent director), age, tenure as director, title, share holdings.

Financial data are from the COMPUSTAT annual industrial file and stock price data are from CRSP. Business segments data are from COMPUSTAT/SEGMENTS. CEO compensation data are from EXECUCOMP. Institutional blockholders data are from Thomson Financial Institutional Holdings 13d. Mergers \& Acquisitions data are from SDC/Platinum. The data for shareholder rights proxy G-Index as in Gompers, Ishii, and Metrick (2003) are from Andrew Metrick. After merging these sources of data there are 15957 firm-year observations from 1996 to 2005 . The particular sample size, however, will depend on different model specifications and data availability. The sample is based on firm-calendar years rather than firm-fiscal years, as in the IRRC data.

As discussed in the introduction, I use IEs as the empirical proxy to test the model of Section 2, as they may possess the required knowledge/ability to advise the management, and their independence status also implies the monitoring function. ${ }^{13}$

I note one potential bias to use this variable as the proxy: some firms may have independent directors who are executive board members of the firms not covered in the IRRC database hence not coded as IEs. Such bias is unlikely to be severe based on two observations. First, since the focus of this study is on those independent directors who may possess high ability to be able to advise the management, and to the extent that executives from smaller firms not covered by IRRC may not possess such required ability, such bias will not be significant. Second, executive board members are more likely to sit as IEs in a smaller- or similar-sized firms as their own firms, and their outside directorships decrease with firm size as I will document later. This further alleviates

\footnotetext{
${ }^{12}$ The coverage is slightly over 1500 firms. IRRC also selectively covers some firms not in the S\&P 1500 but with significant institutional ownership.

${ }^{13}$ One observation from this choice of empirical proxy is that I do not argue ex-ante that no other board members except for IEs will advise the management. In fact, many of them, such as retired executives or academicians may also possess the required ability to advise the management. In a work in progress, I find the rest of independent directors other than IEs seem to advise the management less intensively but monitor better.
} 
the bias.

Proposition 1 and 2 imply that the quality of the CEO turnover decision is lower and the agency costs higher if the board advises. In addition to examining the relation between CEO turnover and the presence of IEs on boards, I use two other measures to proxy for the level of agency costs: CEO compensation and earnings quality as in Ecker, Francis, Kim, Olsson, and Schipper (2006).

CEO turnover is calculated from the IRRC database. A CEO has experienced turnover in a given year (CEO turnover=1) if he no longer serves as the CEO of the same firm at the next annual meeting. To study the influence of corporate boards on the CEO succession decision it would be ideal to focus on forced CEO turnovers. Data availability prevents me from conducting such an analysis. I follow Kaplan and Minton (2006) and use dummy variable for whether the CEO is over 60 to approximate all voluntary resignations such as retirement. ${ }^{14}$ Since I focus on the board's internal monitoring function, I also exclude firm-years for which the firm is a takeover target from the sample.

I examine both the level of CEO compensation and the change of compensation, as in Coles, Daniel, and Naveen (2007). For the level of CEO compensation I examine the CEO annual total pay (Total pay, EXECUCOMP data item TDC1) and two of its components: the cash part of CEO annual pay (Cash pay, salary plus bonus, EXECUCOMP data item TCC) and the Black-Scholes value of the option part of CEO annual pay (Options, EXECUCOMP data item BLK_VALU). I take the logs of these variables to alleviate the concern for outliers. For the change of CEO compensation, I examine the change in CEO annual total pay ( $\Delta$ Total pay).

For earnings quality I use the variable in Ecker, Francis, Kim, Olsson, and Schipper (2006) as the proxy. Dechow and Dichev (2002) use the standard errors from the firm-specific regressions of working capital accruals on last year, this year, and next year's cash flow from operations to proxy for the earnings quality (AQ). Ecker, Francis, Kim, Olsson, and Schipper (2006) augment the Fama and French (1992) three-factor model with this AQ factor and argue that the loading on this factor (Eloading) is a better proxy for earnings quality than other contenders. To the extent that

\footnotetext{
${ }^{14}$ Results using 65 as the cutoff retirement age are qualitatively similar.
} 
Eloading includes both the innate part of the earnings quality and the management discretionary part, it is a noisy measure to examine the board's monitoring function. But as long as Eloadings are associated with lower firm performance, as evidenced in Bradley, Chen, Dallas, and Snyderwine (2007), it still gives some signal for the board's monitoring quality. I take the inverse of Eloading to proxy for the earnings quality since the higher the loading on AQ factor, the more exposure the firm is to earnings risk, hence the lower earnings quality.

To study IEs' advisory function I estimate the link between the corporate policies of the IEs' sender firms and those of the receiver firms. I follow Bertrand and Schoar (2003) and study three types of corporate policies: investment policy, financial policy, and organizational strategy. For investment policy I focus on capital expenditure (Invest) and the number of acquisitions in a given year (Aqr). For financial policy I focus on leverage (Lev), interest coverage ratio (Intcov), cash holdings (Cash), and dividend/earnings (payout) ratio (Div). For organizational strategy I study the firm's number of diversifying acquisitions made in a given year (Daqr), the firm's R\&D expenses (R\&D), advertising expenses (Adver), and SG\&A expenses. Diversifying acquisitions are defined as acquisitions in which the target firm operates in a different industry as the acquirer. I use the 48 industry classifications in Fama and French (1997) throughout the paper. ${ }^{15}$ There are large amount of missing values for R\&D and Adver. I follow Coles, Daniel, and Naveen (2007) and replace the missing values of R\&D by zero. I also replace the missing values of Adver by zero.

For firm performance I follow the convention in the literature and use Tobin's $\mathrm{Q}$ as the proxy. It is defined as the ratio of the market value of the firm's assets to their replacement cost. Accounting convention prevents a precise measure of replacement costs. It is therefore approximated by the book value of the firm's asset. I take the $\log$ of this variable in the regression analysis. I also use accounting performance measures such as return on assets (ROA), return on equity (ROE), return on sales (ROS), sales to assets (STA), and operating return to assets (OPROA) to check the robustness of IEs' performance effect.

To rule out the decreasing-demand as an explanation for the increasingly significant relation

\footnotetext{
${ }^{15}$ Results using two-digit SIC code as the industry classifications are similar.
} 
between IEs and firm performance, I study the difference for the change of director compensation for firms adding IEs versus firms losing IEs after SOX. I use the director annual retainer from EXECUCOMP (data item ANNDIRRET) as the compensation proxy. ${ }^{16}$

Table 1 lists the definition and data source for each variable used in the study.

\subsection{Summary Statistics}

To alleviate the concern of outliers, the CEO compensation variables and all the financial ratios, including corporate policy variables, are winsorized at $1 \%$ percentile. Panel A of Table 2 provides the winsorized summary statistics for the key variables in the study. As can be seen from the table, the median firm's board does not include any IE. In fact, only around one third of the firms have $\operatorname{IE}(\mathrm{s})$ on their board. The average number of IEs is 0.542 , with a standard deviation of 0.933 , suggesting that the presence of IEs on corporate boards is not a common phenomenon and that there are large variations across firms for such presence. The average (median) board also includes 5.59 (5) independent non-executives (INEs), and a total number of 9.5 (9) members. The latter matches the sample mean and median values in Denis and Sarin (1999) closely (9.35 and 9 respectively). On average, directors earn $\$ 23,246$ for retainer annually, which is merely $0.5 \%$ of average CEO's annual total compensation ( $\$ 4.7$ million), suggesting that the main incentive for executives to serve as IEs may not be pecuniary, which is consistent with survey evidence (Neff and Heidrick (2006)).

The fraction of sender firms is $33 \%$, and $34 \%$ for that of receiver firms. The fact that these numbers are similar raises the concern for whether the mutual sitting of executives on each other's boards (interlocking directorships) is a common practice and may drive the potentially low monitoring quality, as in Hallock (1997) and Graham and Wu (2006). Yet the more recent coverage of this sample alleviates such a concern. As argued in Graham and Wu (2006), a consequence of IRS Section $162(\mathrm{~m})$ is the dramatic reduction of interlocking practices among corporate boards, as interlocking directors are characterized by IRS as insiders, so the $\$ 1$ million cap for the tax deductibility of top executives' compensations applies. Consistent with this argument and other

\footnotetext{
${ }^{16}$ This difference-in-difference approach also alleviates the concern for the imprecise director compensation data documented in Farrell, Friesen, and Hersch (2007).
} 
potential forces such as shareholder activisms, I find only $9.3 \%$ of the firms with IEs have interlocking directorships, which is less than half of the value in Hallock (1997)'s 1992 sample (20\%).

Panel B of Table 2 provides a more detailed description of the distribution of IEs by firm size quartiles. Not surprisingly, board size increases monotonically with firm size, and so does board independence. The fraction of IEs on boards also increases with board size. The fraction of receiver firms and the fraction of sender firms also increase with firm size, and the two numbers are very close to each other, suggesting that firms may be inclined to seek executives from similar or larger-sized firms to be independent directors. ${ }^{17}$ I confirm this observation in Panel C.

The last column of Panel B lists the average number of outside directorships for executive board members by size quartiles. This number also increases monotonically with firm size, which further alleviates the bias in using IE as an empirical proxy as discussed in Section 3.1, since it suggests executives from smaller firms not in the IRRC database are less likely to take outside directorships.

In Panel C, I compare the characteristics of the sender firms, including their executive board members' characteristics, to those of the receiver firms. As shown, IEs have a much longer tenure as executive board members than the receiver firms' CEOs (10.4 versus 5.8 years); they are also slightly older (57 versus 55 years old), and they have far more outside directorships (1.9 versus 0.9). These figures are consistent with IEs being knowledgable directors and being in a good position to advise the management.

Consistent with the observations made from Panel B, Panel C indicates that sender firms are similar to receiver firms in terms of size, number of business segments, and performance as measured by Tobin's Q. Sender firms perform slightly better in terms of ROA. In Section 7 I document that the similarity in size between sender and receiver firms is the product of SOX and the effect it had on the number and origin of IEs. In particular, before SOX executive board members sat on slightly smaller firms' boards as IEs. After SOX, this trend is dramatically reversed.

I also compare the corporate policies for the sender and receiver firms. I average a given firm's

\footnotetext{
${ }^{17}$ If a firm seeks IEs from larger firms, and since the largest firms can only seek IEs from their comparable-sized firms, this will also generate the pattern observed in Panel B if I assume executives cannot take too many outside directorships, which is quite plausible given their full-time job in the sender firms.
} 
IEs' sender firms' policy values. It can be seen that for majority of these variables sender firms are significantly different from receiver firms (6 out of 10).

Figure 1 portrays the time trend for the fraction of IEs and INEs to board size over 1996 and 2005. Interestingly, there is generally a downward trend of the fraction of IEs over the sample period. Such a trend seems to flatten right before the passage of SOX in 2002, but resumes afterwards. In contrast, the fraction of INEs has been generally rising during this time period. In Section 7 I argue that these trends are best explained by the increasingly limited supply of executives on the market for directors.

\section{IEs and the Monitoring Function}

I first test for the potential cost of having IEs on boards by examining their monitoring function. If IEs indeed advise the management, as I argued above, Proposition 1 in Section 2 implies that CEO turnover and turnover-to-performance sensitivity will be lower. I test this prediction by running logit regressions for CEO turnover on the number of IEs and other relevant variables. Following Kaplan and Minton (2006), I use the annual stock return as the performance measure and break this measure into three components: the firm stock return relative to industry median stock return, the industry median stock return relative to value-weighted market return, and the value-weighted market return. I also control for proxies for CEO's power relative to the board. I use two such proxies: CEO shareholdings, and a dummy for whether the CEO is also the chairman of the board. As discussed in Section 3, I control for a dummy for whether the CEO is older than 60 to proxy for the voluntary departure (such as retirement) of the CEO. As my focus is on the internal monitoring of the board, I drop the firm-years for which the firm is a takeover target. Following Coles, Daniel, and Naveen (2007) I control for firm size, since large firms' CEO turnover pattern may be quite different from that of small firms. I also control for board size to make sure that the effects of IEs are not driven by IEs' proxying for other type of directors. Throughout the paper I control for Fama and French (1997) 48 industry dummies, year dummies, and a constant term. As suggested in Petersen (2007) and due to the strong auto-correlations of corporate governance variables, standard 
errors are adjusted for heteroscedasticity and clustered at the firm level for all the models in the paper.

The first two columns at Table 3 report the results. Model 1 shows the association between CEO turnover rate and IEs. The coefficient on IE is negative and significant at $10 \%$ level, suggesting that IEs are associated with lower CEO turnover rate, consistent with the model prediction. Unlike Kaplan and Minton (2006), who find that CEO turnover is sensitive to all three measures of firm performance, I find CEO turnover is only sensitive to the industry-adjusted firm returns and not to market-adjusted industry returns or the market returns. This is consistent with relative performance evaluation (RPE) of CEOs, however (Morck, Shleifer, and Vishny (1989), Parrino (1997), Engel, Hayes, and Wang (2003)). Model 2 studies the relation between CEO turnover-to-performance sensitivity and IEs by including an additional control variable: the interaction of a dummy for whether the firm's fraction of IEs to board size is larger than the median value of such fraction for all the firms in a given year (High IE), and the industry-adjusted firm return (Weisbach (1988), Coles, Daniel, and Naveen (2007)). The coefficient on this interaction term is positive and significant at $10 \%$ level, suggesting that IEs are associated with lower CEO turnover-to-performance sensitivity, consistent with the model prediction.

The model in Section 2 predicts that if IEs advise the management agency costs will be higher. I use four proxies for agency costs to examine their associations with IEs: CEO compensation level, the increase of CEO compensation, CEO pay-for-performance sensitivity, and earnings quality.

Since governance variables are typically varying slowly across time, the group-demeaned fixed effect regressions tends to reduce the significance of an independent variable, even though such variable may have explanatory power for the dependent variable (Zhou (2001)). I thus follow Coles, Daniel, and Naveen (2007) and use pooled OLS regressions to study three measures of CEO compensation: Total pay, Cash pay, and Options, as discussed in Section 3.1. Control variables are based on the survey by Murphy (1999): firm performance, firm size, and CEO tenure. I also control for board size. Performance variables include the three performance variables as in Model $1 \&$ 2, and ROA. As in Coles, Daniel, and Naveen (2007) I drop the firm-years in which the CEO 
has experienced turnover and require the CEO's tenure be at least 1 year to eliminate the concern for fractional pay. Columns 3 to 5 in Table 3 report the results. IEs are positively associated with all three measures of CEO compensation. The results are significant at at least $5 \%$ level for Total pay and Cash pay, and marginally significant (at 15\% level) for Options. The coefficient of 0.04 on IE for the Total pay regression suggests that addition of one IE on board, controlling for other relevant factors, increases the CEO total pay by $4 \%$, since the dependent variable is in log term. Using the median value of CEO compensation $\$ 2.5$ million in Table 2, this amounts to an increase of $\$ 100,000$. This is an economically large increase, suggesting that IEs are associated with higher, and statistically and economically significant compensation levels for CEOs.

Obviously, correlation does not suggest causality. It is possible that because of the excessive CEO pay levels shareholders recruit more IEs on boards to solve such problem. In undocumented regressions I use the predicted values based on the coefficients on IE of the regressions in Table 3 to study their associations with future firm performance (Tobin's Q), and find the associations are negative as in Core, Holthausen, and Larcker (1999). These results suggest that IEs indeed cause higher CEO compensation, and such agency costs are negatively associated with future performance.

For CEO pay increase I follow Jensen and Murphy (1990) and use $\Delta$ Total pay as the dependent variable, and use pooled OLS regressions to study its association with IEs and total shareholder dollar return in a given year. As in Coles, Daniel, and Naveen (2007) I also control for board size, CEO tenure, and drop firm-years in which the CEO has experienced a turnover in the current or previous year, and if the CEO's tenure is less than 2 years from the sample. Columns 6 and 7 provide the results.

Column 6 shows that IEs are not only associated with higher CEO total pay, but also larger increase of such pay. The coefficient on IE suggests that addition of one IE on the board, controlling for other factors, is associated with $\$ 83,910$ pay increase for the CEO. This is a dramatic increase based on the median value of $\Delta$ Total pay: $\$ 136,471$ in Table 2.

To study the relation between pay-for-performance sensitivity and IEs, in column 7 I control for 
an additional variable, the interaction term between the High IE dummy as defined above and the dollar return. Though the coefficient on this variable is negative, consistent with IEs decreasing the pay-for-performance sensitivity, it is not significant.

Finally, I study the association between IEs and earnings quality as proxied by the inverse of Eloading. I use pooled OLS regression and control for board size, firm size and firm risk. I use the volatility of stock price over the past 60 months to proxy for the firm risk. The result is presented in the last column in Table 3. It suggests that IEs are negatively and significantly associated with earnings quality.

Overall the results for IEs' monitoring function suggest that IEs are not effective monitors in reducing the agency costs, consistent with their potential advisory role as predicted by the model in this paper. I thus examine whether they indeed advise the management in the next section, and whether this potential advisory benefit exceeds the associated higher agency costs in Section 6.

\section{IEs and the Advisory Function}

As documented in Kaplan and Reishus (1990), Booth and Deli (1996), Perry and Peyer (2005) and Fich (2005) the probability of executives taking outside directorships increases with their firms' performance. Fich (2005) further suggests that firms hire executives as outside directors to utilize their expertise. If such expertise is manifested through proper choice of corporate policies in managing their sender firms, it is quite natural to hypothesize that they may choose to advise the receiver firm's management using insight from their own firms' policies. This is also consistent with IEs being very busy people as I will document later, since busyness means they may not be able to exert much effort to advise the management on a firm-specific basis. I thus test the correlations between the sender firms' corporate policies and those of the receiver firms' to identify their advisory function. The arguments above suggest that these correlations should be positive. Table 4 reports the results.

Since only firms with an IE are included in the sample for the test, the sample size is dramatically reduced as compared with Table 3. Each dependent variable in the table is a corporate policy 
variable as discussed in Section 3.1. I use OLS regressions to study the correlations between the firm's corporate policy and the corresponding average policy values of all the IEs' own firms (AveIEX, where $\mathrm{X}$ is the corporate policy variable), controlling for other firm-specific determinants of the policy. These control variables follow Bertrand and Schoar (2003). I consider the possibility that interlocking of directorships might generate mutual advising hence making the OLS estimates inconsistent, so I dropped all the firm-year observations with interlocking directorships. ${ }^{18}$ All the coefficients on AveIEX in Table 4 are positive, consistent with expectations. Furthermore, the coefficients on Invest, Cash, Div, R\&D, and SG\&A are significant, suggesting that IEs may have stronger influence on these corporate policies than others.

Other potential hypotheses may also explain these positive correlations. First, if IEs conduct their monitoring function on these corporate policies effectively, as Raheja (2005), Adams and Ferreira (2007), and Harris and Raviv (2007) suggest, they could also potentially influence these values chosen by the management which may not be in the best interest of shareholders (such as conducting too many acquisitions for empire building). I call this the "monitoring hypothesis". Yet the key feature of the monitoring function as identified in these literature is the active involvement of the board in the determination of key corporate strategies. ${ }^{19}$ Such involvement will require exerting effort which is implausible especially for IEs due to their busyness. I thus test the "monitoring hypothesis" by examining the busyness of IEs using two measures: the total number of outside directorships and whether they miss $75 \%$ of the board meetings, in addition to the evidence in Panel C of Table 2, where I document that the number of outside directorships for sender firms' executives is more than twice the number of outside directorships for receiver firm's CEOs. I compare these two measures for IEs vs. INEs. Panel A of Table 5 reports the results. IEs on average hold 1.91 outside directorships, compared with only 1.20 for INEs. Their fraction to miss at least $75 \%$ of the board meetings is twice as many as such fraction for INEs. This evidence confirms the busyness of IEs. Furthermore, using the classification of three total board memberships as "busy"

\footnotetext{
${ }^{18}$ This may not fully eliminate the concern, however, since directors can have influence on each other's corporate policies through a chain of networks. I thus also use 3SLS to study the simultaneous determination of the sender and receiver firm's corporate policies and obtain similar results as OLS.

${ }^{19}$ The literature uses a cost function to proxy for such involvement.
} 
in Fich and Shivdasani (2006), IEs' average total number of directorships $2.91(1.91+1)$ also puts them in the category of "busy" directors. Such busyness is inconsistent with their potential influence on corporate policies through the monitoring function, but still consistent with the advisory function which allows for a more hands-off approach.

Second, the positive correlations between sender and receiver firms' policies may come from executives from the same industry and policy similarities for firms within the same industry. I term this as the "industry hypothesis". This is related to the monitoring hypothesis, since one could argue that IEs from the same industry are familiar with the business that they do not have to spend much effort to monitor the management. First, I note that only $17.3 \%$ of the receiver firms have at least one IE from the same industry (in terms of his/her sender firm), which suggests that the vast majority of IEs cannot be too familiar with the business of the firm to make the effort exertion less of a concern. But it could still be possible that the positive correlations are driven by this group of IEs from the same industry. I then test this hypothesis formally by including an additional variable for the models of Table 4, an interaction term between a dummy for whether at least one IE on the board comes from the same industry (Same industry) and AveIEX as defined above. If the industry hypothesis holds, the positive correlations documented above should be fully captured by this interaction term. Yet the results in Panel B of Table 5 suggest that the coefficients on AveIEX which are significant in Table 4 (Invest, Cash, Div, R\&D, and SG\&A) are still significant after the interaction term is included. The interaction terms are also significant, which might suggest that IEs from the the same industry advise the management differently from other IEs. ${ }^{20}$

Third, the positive correlations between sender and receiver firms' policies may come from a matching of IEs based on firms' corporate policies. It is possible that a CEO brings a colleague on the board who shares with him the same view on corporate policies, but the latter may not bring additional insight into the decision making process. I term this the "matching hypothesis". First, as noted in Güner, Malmendier, and Tate (2007), it might be plausible for an IE to share the same

\footnotetext{
${ }^{20}$ One may naturally imagine that IEs from the same industry may advise more intensively than other IEs. This suggests the interaction term should be positive. But it is also possible that IEs from the same industry advise less intensively because of the potential competition between their sender firms and the receiver firms. This suggests that the interaction term should be negative. The results in Panel B of Table 5 give evidence for both hypotheses.
} 
view with the CEO on a single or limited number of corporate policies, but it is not very likely that they would share the same view on the scope of the corporate policies documented in Table 4. In fact, even if this hypothesis holds for a single policy, such scope of corporate policies suggests that IEs still influence other corporate policies once they are recruited. Second, it is harder for this "matching hypothesis" to explain the more senior profiles of IEs as managers than the receiver firms' CEOs, and the evidence that a majority of the corporate policies are significantly different for the sender and receiver firms as documented in Panel $\mathrm{C}$ of Table 2. Third, it is also harder for this hypothesis to explain much of the survey evidence that firms seem to desire the service of the directors who would broaden the management's perspective. I nevertheless formally test this hypothesis by testing the strength of the correlations between the sender and receiver firm's corporate policies, depending on whether the executive sits on the board as an IE or not.

To conduct this test, I use director-firm-year observations rather than firm-year observations to run the OLS regressions. This means for a single firm in a given year there can be multiple observations if the firm has more than one IE. To construct the sample, I track every executive board member who served as an IE within the period from 1996 to 2005, and delete those IE-firmyear observation for which the executive switches firms to be the manager (to make sure that the potential different strength of the correlation is not due to two different sets of firms), and those IE-firm-year observations for which the executive sits as an IE for the whole period. In effect, the sample includes those IE-firm-year observations for which either initially the executive did not sit as an IE but later joined the board, or initially the executive sat as an IE but later departed from the board, or both. I regress each corporate policy value on the corresponding value of each IE's sender firm (IEX). I control for an interaction term for whether the executive is on the board (Executive sits as IE) and IEX. Results are reported in Panel C of Table 5. If the matching hypothesis fully explains the positive correlations between sender and receiver firms' corporate policies, one should not expect the interaction term to be significant. But the results in the table suggest the interaction term on Cash and Div are marginally significant and the coefficient on IEX is not significant, which suggests that the correlations between sender and receiver firms' policies are not significant unless 
the executives sit on boards as IEs. This is clearly inconsistent with the matching hypothesis. The results for R\&D and SG\&A, however, give some support for this hypothesis. But as noted above, this might simply suggest that IEs may be recruited on the board based on the matching of some policies between the receiver and sender firms, but they still influence other policies through their advisory function.

Overall, the results in Table 5 are not consistent with alternative hypotheses fully capturing the positive correlations between sender and receiver firms' corporate policies. These results together with the evidence in Table 4 are most consistent with IEs' advisory function.

The remaining question is how the presence of IEs affects the corporate policies on average out of the advisory pattern as documented above. This will ultimately determine whether IEs indeed bring benefit to firms through their advisory function. To answer this question, I use pooled OLS regressions to examine the effect of the number of IEs on the policy variables, controlling for board size and the same set of variables as in Tables 4 and 5. ${ }^{21}$ Table 6 lists the results. Since I'm using the number of IEs to run the regressions, the samples include those firms without any IEs, which are much larger than those reported in Tables 4 and 5. The results in the table suggest that the more IEs, the lower Invest and Lev, the higher Div, R\&D, and SG\&A. ${ }^{22}$ These results suggest that IEs' advisory function has significant effects on some corporate policies. Whether such effects are beneficial to the firm, however, is not clear from these regressions. I thus examine in the next section whether the documented advisory function for IEs brings benefit to the firm, and whether such benefit exceeds the associated higher agency costs.

\section{IEs and Firm Performance}

The results in Table 3 suggest that IEs are ineffective monitors and are associated with higher agency costs. Table 6 documents that IEs influence several corporate policies through their advi-

\footnotetext{
${ }^{21}$ One may question whether this average effect is indeed due to such pattern of advice. As long as on average IEs' sender firms are associated with certain direction of policy values, and such direction agrees with the sign on the average effect of IEs on such policy (for example, on average IEs come from firms with higher dividend payout ratio, and the average effect of IEs on receiver firm's dividend policy is also positive), as I confirm is generally the case, this average effect is still due to such pattern of advice.

${ }^{22}$ The result for Invest is not robust excluding finance \& utility firms from the sample, as I discuss in Section 8.4.
} 
sory function. To determine whether the potential benefit of IEs' advisory function exceeds the costs, I examine the relation between IEs and firm performance. I use Tobin's Q as the performance measure. Control variables are based on a survey of prior literature (Gompers, Ishii, and Metrick (2003), Coles, Daniel, and Naveen (2006), Graham, Hazarika, and Narasimhan (2007)), which include board size, Lev, ROA, number of institutional blockholders with at least $5 \%$ holdings (Block holders), G-Index, the incentive part of the CEO compensation (CEO incentive), firm size (Firm size), R\&D, Invest, intangible assets (Intangible assets), firm age (Firm age), the number of business segments (Business segments), and a dummy for whether the firm is in the S\&P 500 index (S\&P 500 index). I use pooled OLS regressions and take the log of Tobin's Q to run the regression. Model 1 of Table 7 presents the result.

The result in Model 1 suggests that IEs are strongly (at 1\% level) and positively associated with firm performance. Since the dependent variable is in log term, the coefficient on IE (0.024) suggests that adding one more IE on the board, with other variables fixed, increases Tobin's Q by $2.4 \%$, which is also economically significant. It is also notable that the coefficients on Lev and R\&D have the same signs as the correlations between IEs and these two variables as in Table 6 , which suggests that IEs' advice on these two policies are beneficial to the firm. The coefficient on Invest, however, is positive and strongly significant which is opposite to the correlation between IE and this variable. This result seems to suggest that IEs' advising is detrimental to the firm. I will document two pieces of evidence that is not consistent with this argument in Section 8. First, the significant impact of IEs on Invest disappears when I exclude finance \& utility firms from the sample. Since these firms generally have quite different investment patterns as noted in Bertrand and Schoar (2003), this result suggests IEs' influence on this variable is not robust. Second, when I include the lagged value of Tobin's Q in the performance regression to control for endogeneity of Tobin's Q in the performance regression, the coefficient on Invest becomes negative and significant. Since investment might respond to Tobin's Q (which also proxies for the incentive for firms to invest), this result suggests that firms might over-invest by observing Tobin's Q. If this holds, then IEs' negative effect on investment is not harmful, but beneficial after all. The result in 
Model 1 suggests that IEs' advisory function brings benefit to the firm, and such benefit exceeds the associated higher agency costs.

Since IEs also significantly influence the firms' Div, Adver, and SG\&A, I control for these additional variables in Tobin's Q regression to examine further whether IEs' associations with these variables bring benefits to the firm. Model 2 of Table 7 reports the results. The coefficients on these three variables are all positive, which agree with the signs of their correlations with IE in Table 6. These results further suggest that IEs on average are good advisors. It is also notable that even after all the corporate policy variables that are significantly influenced by IEs have been controlled for, IE is still significant. I test alternative hypotheses in the next section to explain this significant relation.

Proposition 3 in the theory suggests that unless IEs' abilities are sufficiently high they should not advise. To test this prediction, I use firm size that an executive can manage to proxy for his ability, as argued in Rosen (1982) and evidenced in Hayes and Schaefer (1999). In Model 3 of Table 7 I include an interaction term for whether the average size of all IEs' sender firms is greater than the receiver firm (Dummy(IE_Firm size $>$ Firm size)) and IE. I expect this interaction term to be positive if IEs with higher abilities improve firm performance better. Indeed, the result confirms this prediction: the interaction term is positive and highly significant (at $5 \%$ level). In addition, IE loses significance after this interaction term has been controlled for, which suggests that the positive effect of IEs on performance is driven by those IEs with high abilities, if firm size which they can manage proxies for such ability. This is consistent with the prediction of the model, but inconsistent with the proposition in Adams and Ferreira (2007), that it is always desirable for the board to have an advisory function.

\section{Explaining The Significant Relation Between IEs and Firm Performance}

Demsetz and Lehn (1985) argue that if firms behave optimally, all the relevant variables have been controlled for, and there are no market frictions (such as transaction costs and limited supply of qualified directors), no significant relation should be expected for a governance variable and 
firm performance. IEs' positive relation with firm performance suggests that the board might act optimally in balancing the two functions. I document evidence in Section 8.1 that suggests firms seem to understand the tradeoff between the two functions that they place more IEs on their boards when their demand for outside advice is higher. I test for other hypotheses that could potentially explain the significant relation between IEs and firm performance.

I use the passage of SOX and its associated change in corporate environment as a natural experiment for this test. As much survey evidence suggests (Daum and Neff (2005)), post-SOX it is harder for firms to recruit qualified directors due to the heightened litigation risk to serve as directors. Many companies limit the number of outside directorships for their executives to make them focus on managing their own business. As a result, the supply of executives to be potential IEs may be (further) limited post-SOX. If the scarcity of IEs drives their significant relation with firm performance, I should expect such relation to be even stronger post-SOX. In contrast, SOX does not imply a significant change of the relation between IEs and firm performance based on other hypotheses, such as transaction costs and missing relevant variables. Hence, it offers an ideal environment to differentiate between these hypotheses.

Though the survey evidence suggests that the argument for the limited supply of executives is quite plausible, it is theoretically possible that the generally downward trend for IEs observed in Figure 1 is due to firms' decreasing demand for IEs, especially in light of the model and evidence above, that IEs are not effective monitors. If post-SOX risk increases dramatically for not being effective monitors, firms may find it optimal to remove IEs from their boards to avoid the potential larger loss of firm value due to shareholder litigations. I test this shrunken-demand hypothesis by examining the change of director compensation for firms losing IEs $(\Delta \mathrm{IE}<0)$ versus those adding IEs $(\triangle \mathrm{IE}>0)$ post-SOX. I use the annual director retainer to proxy for director compensation. I match these two groups of firms by industry and size. I set 2002 as the last pre-SOX year since SOX was passed in August, 2002. I calculate the change of the annual director retainer between 2002 and 2005, and calculate the t-statistic for the difference of such change across the two groups of firms. Panel A of Table 8 lists the results. Both sets of firms increase the compensation to attract 
the directors. But the firms with $\Delta \mathrm{IE}>0$ increases significantly more compared with firms with $\Delta \mathrm{IE}<0$ (at 2\% level), which is not consistent with the shrunken-demand of IEs.

I then document a dramatic shift of the demographics of IEs post-SOX. As the evidence in Panel B of Table 2 suggests, executives from larger firms take significantly more outside directorships than executives from smaller firms. This implies that the former may decrease their directorships more than the latter, since they were busier pre-SOX. In Panel B of Table 8 I test this hypothesis by examining the difference between the change of the number of outside directorships for executive board members from the largest size quartile compared with executive board members from the smallest size quartile. As can be seen, executive board members from large firms decreases their outside directorships significantly (at 5\% level), compared with the insignificant change for those from small firms, which is consistent with this hypothesis.

This pattern of the change of outside directorships would imply that the average size of IEs' sender firms should shrink post-SOX relative to the receiver firms, as I document in Panel C of Table 8. It is interesting to note that before SOX, executives sit on slightly smaller boards to be IEs (significant at $13 \%$ level), but such pattern is dramatically reversed post-SOX (significant at $2 \%$ level).

As I argued in Section 6, if the firm size that an executive can manage serves as a proxy for his ability, this change of the demographics of IEs suggests that on average the talent pool of all IEs shrank post-SOX, which implies an even stronger relation between IEs from larger firms and firm performance. I formally test this prediction in Panel D of Table 8, by including an additional interaction term as Model 3 of Table 7, the product of Dummy(IE_Firm size $>$ Firm size), IE and a dummy for whether the year is post-SOX (after 2002, SOXyear). Indeed, this interaction term is positive and significant at $5 \%$ level, consistent with the prediction.

These results suggest that the significant relation between IEs and firm performance is driven by the scarcity of IEs on the market for directors, particularly those whose abilities are high as proxied by their sender firms' sizes. SOX and its associated corporate environment further discourages the supply of those executives to serve as IEs, which imposes a cost for all the firms desiring their 
service. $^{23}$

\section{Robustness Checks}

I run additional regressions to confirm the robustness of the results established in the former sections.

\subsection{IEs and Firms' Demand for Advice}

This section gives further evidence for IEs' advisory function, by examining the relation between the number of IEs and firms' demand for outside advice. Given IEs' advisory function as documented in Section 5, the results also suggest that firms understand the tradeoff between the higher agency costs associated with them and their advisory benefit, and bring more IEs to their boards only when they need their advice the most. I use the three measures as in Coles, Daniel, and Naveen (2006) to proxy for firms' demand for advice: the firm's sales revenue, Lev, and Business segments. Coles, Daniel, and Naveen (2006) argue that the higher these values the more complex the firm is, hence the higher the demand for advice. Since these variables tend to be positively correlated with each other, I follow Coles, Daniel, and Naveen (2006) and use factor analysis to reduce the three variables to a single factor score (Advice). I use OLS regression to study the relation between the number of IEs and Advice, controlling for other relevant variables. I follow the current literature on the determinants of the composition of the board (such as Boone, Field, Karpoff, and Raheja (2007)) to control for board size, firm performance (Tobin's Q and ROA), R\&D, G-Index, CEO tenure and age, intangible assets and firm age. Column 1 in Table 9 reports the result.

\footnotetext{
${ }^{23}$ One may argue that IEs should capture all the economic rents due to their scarcity, rendering the receiver firms no net benefits in recruiting IEs. If the economic rents are in terms of director compensation, the rising trend of such compensation as documented in Panel A of Table 8 seems to be consistent with this argument. In undocumented analysis I control for director annual retainer as an additional variable in the Tobin's Q regression and find IE is significant. To possibly explain this result, I note that each director receives the same annual retainer for a given firm. This suggests that firms may have to balance between directors with different abilities and set the compensation accordingly (see, e.g., the model in Farrell, Friesen, and Hersch (2007). If IEs are at the high end of the ability spectrum this practice implies IEs cannot capture all the rents. A second explanation for IEs' inability to capture all the rents is that the incentive for executives to serve as IEs is not pecuniary for the most part. As many survey evidence suggests (e.g. Neff and Heidrick (2006)), the biggest reasons for them to take outside directorships include reputation of the company and its financial condition, and the experience that can be applied to their own firms. If this is true, then serving as IEs for executives may be beneficial for both the receiver firms and themselves, which suggest they do not capture all the rents.
} 
The coefficient on Advice is positive and strongly significant (at better than $1 \%$ level), which suggests that when firms demand more outside advice they recruit more IEs to their boards. This provides further evidence for IEs' advisory function. It also suggests that firms seem to understand the tradeoff between the two functions and bring more IEs when their demand for their advice is higher. In column 2 I examine whether the positive effect of IEs on performance is significant only when their advisory function brings the highest benefit to overcome their potential costs, by including an interaction term for a dummy of whether the firm's Advice is greater than the median value of Advice for all the firms in a given year (Advice dummy) and IE, in the Tobin's Q regression as Model 2 of Table 7. Consistent with expectations, this interaction term is positive and significant at 5\% level. Furthermore, the coefficient on IE becomes negative and insignificant.

Since governance variable and firm performance tend to be mutually determined (Hermalin and Weisbach (2003)) the estimates in Tables 7 and 9 may be biased. To overcome this issue, I use 3SLS to study the simultaneous determinations of Tobin's Q and IE. The last two columns in Table 9 report the results. Advice is still positive and strongly significant in the IE regression, so is IE in the Tobin's Q regression, confirming IE's positive impact on firm performance with the potential endogeneity considered. As is well known, this structural estimation methodology is sensitive to model specifications. I thus examine further the endogeneity issue between performance and IE in Section 8.2.

\subsection{Causality Between IEs and Tobin's Q}

The endogenous determination of board composition and its causal relation with firm performance has been the focus of recent study on corporate boards (Hermalin and Weisbach (1991), Bhagat and Black (2002), Duchin, Matsusaka, and Ozbas (2007)). I thus run additional tests to examine the causality between IEs and Tobin's Q. In Model 1 of Table 10 I use the lagged values of IE and board size in the Tobin's Q regression. The coefficient on the lagged value of IE is still positive and significant (at 10\% level). In Model 2 I follow Klein (1998) and control for the lagged value of Tobin's Q to alleviate the concern for endogeneity. The effect of IEs on firm performance is still positive and strongly significant (at $1 \%$ level). It is also notable that the sign on capital expenditure 
changes to negative. Since Tobin's Q can also be interpreted as firm's incentive to invest, this result suggests that firms may overinvest after observing last period's Tobin's Q. If this is the case, the negative impact of IEs on capital expenditure as documented in Table 6, does not imply that IEs' advising on this policy is detrimental to firm performance, but to the contrary.

Finally, I use SOX and its associated corporate environment as a natural experiment to further test the positive effect of IEs on firm performance (see Duchin, Matsusaka, and Ozbas (2007) for related work on using SOX to test the relation between independent directors as a whole and firm performance). As argued in Section 7, SOX may have forced executives to reduce their outside directorships. But since SOX and the exchange listing standards also impose a higher requirement for the independence of the board, firms may demand more executives to serve as IEs to satisfy the independence requirement. I thus compare the difference for the change of Tobin's Q for the firms with $\Delta \mathrm{IE}>0$ compared with firms with $\Delta \mathrm{IE}<0$, with the implicit assumption that both changes might be exogenous. For that purpose I run OLS regression for all the firms with changing number of IEs between 2002 and 2005, for their change of Tobin's Q on the change of IEs. I only include firms with changing number of IEs to potentially increase the power of the test. Since the sample size is small (only 210 observations) I only include two additional control variables: the change of board size and the change of firm size during this time period, since I also control for FamaFrench 48 industry effects. Model 3 of Table 10 gives the result. The coefficient on $\Delta$ IE is positive and marginally significant at $10 \%$ level, suggesting that adding IEs improves firm performance compared with losing IEs.

To alleviate the concern for whether the change of IEs is indeed exogenous since the regulations do not directly impose requirements for the composition of IEs, I run similar regression for firms pre-SOX. To be more comparable with the result in Model 3, I consider a three-year interval between 1999 and 2002 as the pre-SOX period. If firms face less exogenous constraints to recruit IEs pre-SOX, the change of IEs on firm performance should be less significant or insignificant. This is confirmed in Model 4 of Table 10. As shown, the coefficient on $\Delta \mathrm{IE}$ is almost zero and insignificant, consistent with firms' facing less outside constraints in adjusting their IEs. 


\subsection{IEs and Accounting Performance}

To further check the robustness of the positive relation between IEs and firm performance, I run regressions for accounting performance on IEs. I check ROA, ROE, ROS, STA, and OPROA. Formal definitions of these variables are in Table 1. As in Bertrand and Schoar (2003) I control for firm size. I use OLS regressions. I also control for board size, Fama-French 48 industry effects and year effects, and a constant term. The results are omitted for space concern.

IEs are positively correlated with all five measures of accounting performance. Four of the correlations are significant. Specifically, ROA is significant at the $10 \%$ level, ROE is significant at the 5\% level, and STA and OPROA both are highly significant at the $1 \%$ level. These results further confirm that IEs improve firm performance.

\subsection{Results Without Finance \& Utility Firms}

As is well known, finance \& utility companies make quite different investment decisions. Much of the literature on corporate governance also exclude finance \& utility firms from their analysis based on the argument that the governance functions may be quite different for these companies due to their closely regulated environment. I thus run all the regressions deleting finance \& utility firms (2-digit SIC code 49 or 1-digit SIC code 6). All the results qualitatively remain the same and are omitted to save space. Some notable differences include:

1. For Panel C of Table 5 the significance for the interaction term "IEX * Executive sits as IE" disappears for cash holdings and dividend policy. However, when I run less restrictive regressions

for the two samples depending on whether executives are on the boards as IEs or not (instead of using one sample but including an interaction term) the results are more robust.

2. The average effect of IEs on Invest (Table 6) becomes insignificant. This is not surprising since finance \& utility firms generally make quite different investment decisions.

\subsection{Alternative Econometric Models}

Finally, I check the robustness of the results by using alternative econometric models other than OLS. 
Since IE is defined as the number of independent executives, a Poisson model might be more preferable than OLS in the regressions of IEs on firms' advising demand. I thus use a Poisson model to run regression for Model 1 of Table 9 but did not find any qualitatively different results. Similarly, I run Poisson regressions for Aqr and Daqr in Table 4, 5, and 6. All the results are similar except for the model for Daqr in Table 4, where the coefficient for AveIEDaqr becomes marginally significant at $10 \%$ level.

Since the other corporate policy variables are all positive I run a Tobit model together with bootstrap method (with 50 replications) to calculate the standard errors in Table 4, 5, and 6. The results are similar and generally stronger. In particular, Adver becomes significant at $1 \%$ level in Table 4, and significant at 5\% level in Panel B of Table 5. The interaction term "IEX * Executive sits as IE" in Panel C of Table 5 becomes insignificant for Cash but strongly significant at $1 \%$ level for Div. The results in Table 6 are also stronger. In particular, interest coverage ratio is negatively and significantly (at 5\% level) affected by IEs with a Tobit model.

\section{Conclusion}

This paper derives the optimal tradeoff between the two primary functions of the board of directors: monitoring and advising management. The model predicts that advising management results in lower monitoring quality and higher agency costs. Therefore, independent directors should not advise unless their abilities are sufficiently high.

Using IEs as the empirical proxy for the board's ability to advise management, I test the predictions of the model and find supportive evidence. I find that more IEs on boards is associated with lower CEO turnover and turnover-to-performance sensitivity, higher CEO pay and pay increase, and lower pay-for-performance sensitivity and earnings quality. I then document IEs' advisory function directly by correlating the corporate policies between their own firms and the receiver

firms. I rule out alternative hypotheses that could potentially explain such positive correlations, and find IEs' presence on boards is associated with several corporate policy variables. I also find IEs are positively, significantly, and causally associated with firm performance, suggesting that 
their advisory benefit exceeds the associated higher agency costs. Finally, I argue that the significant relation between IEs and firm performance is due to the scarcity of IEs on the market for directors, and use SOX as a natural experiment to demonstrate the validity of this argument.

Two caveats are noted for interpretations of these results. First, though I have argued in the paper that the evidence fits well with the economic model described in Section 2, other potential theories may also be able to explain the evidence. For example, since IEs are executives themselves, their sympathy for the receiver firm's management may drive the low monitoring quality, consistent with the sociological view as in Westphal and Zajac (1997).

Second, I have used the size of the firm that the executive manages to proxy for his/her ability, as in Rosen (1982) and Hayes and Schaefer (1999). But this variable can be interpreted multiple ways. For example, the variable Dummy(IE_Firm size $>$ Firm size) may also capture the relative size of the receiver firm. A dummy that equals 1 may simply mean the receiver firm's size is small and since smaller firms have higher performance controlling for other variables as in Table 7, the interaction term for this dummy and IE may capture this "small size" effect. In undocumented analysis I explored an alternative specification by directly controlling for the average size of all IEs' sender firms and found a positive and significant coefficient for this variable. Since this variable is positively correlated with the receiver firm's size (correlation coefficient around 0.3), this suggests that a "small size" effect cannot explain all the significance on the interaction term. To completely rule out such an explanation, however, requires a more direct measure of an executive's ability, which is hard to assess in general.

The paper can be extended in several directions. First, one of the reasons to use IEs as the empirical proxy is to take advantage of the potential identifiability for their advisory function. This identification strategy can be extended to other types of independent directors. For example, since a significant part of INEs are retired executives, one may compare the corporate policies they chose for the firms where they served as the managers to those of the firms they are IEs, to identify their potential advisory function.

Second, I have focused on one type of independent directors (IEs), and use it as the empirical 
proxy to test my theory. A more powerful test might be to compare the monitoring quality and advisory effect of different types of independent directors. Of course, identification of the advisory function in general is hard. In an ongoing project along this line of research, I compare different behaviors of IEs and INEs and the evidence suggests that IEs are worse monitors than INEs but are more intensive advisors than the latter, consistent with the tradeoff between the two functions. ${ }^{24}$ More work needs to be done to draw any conclusions, however.

\footnotetext{
${ }^{24}$ The results are based only on their differential effects on corporate policies as in Table 6 , since identification of the direct advising pattern as in Table 4 and 5 is hard for INEs in general.
} 


\section{References}

Adams, Renee B., and Daniel Ferreira, 2007, A theory of friendly boards, The Journal of Finance LXII, 217-250.

Agrawal, Anup, and Charles R. Knoeber, 2001, Do some outside directors play a political role?, Journal of Law and Economics XLIV, 179-198.

Bertrand, Marianne, and Antoinette Schoar, 2003, Managing with style: The effect of managers on firm policies, Quarterly Journal of Economics CXVIII, 1169-1208.

Bhagat, Sanjai, and Bernard Black, 2002, The non-correlation between board independence and long-term firm performance, Journal of Corporation Law 27, 231-273.

Boone, Audra L., Laura Casares Field, Jonathan M. Karpoff, and Charu G. Raheja, 2007, The determinants of corporate board size and composition: An empirical analysis, Journal of Financial Economics 85, 66-101.

Booth, James R., and Daniel N. Deli, 1996, Factors affecting the number of outside directorships held by CEOs, Journal of Financial Economics 40, 81-104.

,1999, On executives of financial institutions as outside directors, Journal of Corporate

Finance 5, 227-250.

Bradley, Michael, Dong Chen, George Dallas, and Elizabeth Snyderwine, 2007, Corporate governance, credit ratings, and bond spreads, Working Paper, Duke University.

Carter, Colin B., and Jay W. Lorsch, 2004, Back to the Drawing Boards: Designing Corporate Boards For A Complex World (Harvard Business School Press: Boston).

Coles, Jeffrey L., Naveen D. Daniel, and Lalitha Naveen, 2006, Boards: Does one size fit all?, Journal of Financial Economics Forthcoming.

— , 2007, Co-opted boards: Costs, benefits, causes, and consequences, Working Paper, Arizona State University. 
Core, John E., Robert W. Holthausen, and David F. Larcker, 1999, Corporate governance, chief executive officer compensation, and firm performance, Journal of Financial Economics 51, 371406.

Daum, Julie Hembrock, and Thomas J. Neff, 2005, Changes at the top: What the new regulations mean for director recruiting, SpencerStuart Research \& Insight.

Dechow, Patricia M., and Ilia D. Dichev, 2002, The quality of accruals and earnings: The role of accrual estimation errors, The Accounting Review 77, 35-59.

Demsetz, Harold, and Kenneth Lehn, 1985, The structure of corporate ownership: Causes and consequences, Journal of Political Economy 93, 1155-1177.

Denis, David J., and Atulya Sarin, 1999, Ownership and board structures in publictly traded corporations, Journal of Financial Economics 52, 187-223.

Duchin, Ran, John G. Matsusaka, and Oguzhan Ozbas, 2007, When are outside directors effective?, Working Paper, University of Southern California.

Ecker, Frank, Jennifer Francis, Irene Kim, Per M. Olsson, and Katherine Schipper, 2006, A returnsbased representation of earnings quality, The Accounting Review 81, 749-780.

Engel, Ellen, Rachel M. Hayes, and Xue Wang, 2003, CEO turnover and properties of accounting information, Journal of Accounting and Economics 36, 197-226.

Ezzamel, Mahmoud, and Robert Watson, 1997, Wearing two hats: The conflicting control and management roles of non-executive directors, in Steve Thompson Kevin Keasey, and Mike Wright, ed.: Corporate Governance: Economic, Management, and Financial Issues (Oxford University Press: New York).

Fama, Eugene F., 1980, Agency problems and the theory of the firm, Journal of Political Economy 88, 288-307. 
— , and Kenneth R. French, 1992, The cross-section of expected stock returns, The Journal of Finance XLVII, 427-465.

_ 1997, Industry costs of equity, Journal of Financial Economics 43, 153-193.

Fama, Eugene F., and Michael C. Jensen, 1983, Separation of ownership and control, Journal of Law and Economics 26, 301-326.

Farrell, Kathleen A., Geoffrey C. Friesen, and Philip L. Hersch, 2007, An examination of director compensation: The roles of benchmarking and asymmetry, Working Paper, University of Nebraska-Lincoln.

Fich, Eliezer M., 2005, Are some outside directors better than others? evidence from director appointments by Fortune 1000 firms, Journal of Business 78, 1943-1971.

— and Anil Shivdasani, 2006, Are busy boards effective monitors?, The Journal of Finance LXI, 689-724.

Gompers, Paul, Joy Ishii, and Andrew Metrick, 2003, Corporate governance and equity prices, Quarterly Journal of Economics 118, 107-155.

Graham, John R., Sonali Hazarika, and Krishnamoorthy Narasimhan, 2007, Corporate governance, debt, and investment policy during the great depression, Working Paper, Duke University.

Graham, John R., and Yonghan Julia Wu, 2006, Executive compensation, interlocked compensation committees, and the 162(m) cap on tax deductibility, Working Paper, Duke University.

Grinstein, Yaniv, and Vidhi Chhaochharia, 2005, Corporate governance and firm value-the impact of the 2002 governance rules, The Journal of Finance Forthcoming.

Güner, A Burak, Ulrike Malmendier, and Geoffrey Tate, 2007, Financial expertise of directors, Journal of Financial Economics Forthcoming.

Hallock, Kevin F., 1997, Reciprocally interlocking boards of directors and executive compensation, Journal of Financial and Quantitative Analysis 32, 331-344. 
Harris, Milton, and Artur Raviv, 2007, A theory of board control and size, Review of Financial Studies Forthcoming.

Hayes, Rachel M., and Scott Schaefer, 1999, How much are differences in managerial ability worth?, Journal of Accounting and Economics 27, 125-148.

Hermalin, Benjamin, and Michael Weisbach, 1991, The effects of board composition and direct incentives on firm performance, Financial Management 20, 101-112.

- 2003, Boards of directors as an endogenously determined institution: A survey of the economic literature, FRBNY Economic Policy Review 9, 7-26.

Holmström, Bengt, 1999, Managerial incentive problems: A dynamic perspective, Review of Economic Studies 66, 169-182.

Jensen, Michael C., and William H. Meckling, 1976, Theory of the firm: Managerial behavior, agency costs and ownership structure, Journal of Financial Economics 3, 305-360.

Jensen, Michael C., and Kevin J. Murphy, 1990, Performance pay and top-management incentives, Journal of Political Economy 98, 225-264.

Kaplan, Steven N., and Bernadette A. Minton, 2006, How has CEO turnover changed? increasingly performance sensitive boards and increasingly uneasy CEOs, NBER Working Paper No. W12465.

Kaplan, Steven N., and David Reishus, 1990, Outside directorships and corporate performance, Journal of Financial Economics 27, 389-410.

Klein, April, 1998, Firm performance and board committee structure, Journal of Law and Economics XLI, 275-303.

Linck, James S., Jeffry M. Netter, and Tina Yang, 2007, The effects and unintended consequences of the Sarbanes-Oxley Act on the supply and demand for directors, Working Paper, Terry College of Business, University of Georgia. 
Lorsch, Jay W., and Elizabeth MacIver, 1989, Pawns or Potentates: The Reality of America's Corporate Boards (Harvard Business School Press: Boston).

Lucchetti, Aaron, and Monica Langley, 2007, In Citi shake-up, broader troubles-perform-or-die culture leaves thin talent pool for top wall street jobs, November 5, The Wall Street Journal.

Mace, Myles L., 1986, Directors: Myth and Reality (Harvard Business School Press: Boston).

Monks, Robert A.G., and Nell Minow, 2004, Corporate Governance (Blackwell Publishing).

Morck, Randall, Andrei Shleifer, and Robert W. Vishny, 1989, Alternative mechanisms for corporate control, The American Economic Review 79, 842-852.

Murphy, Kevin J., 1999, Executive compensation, in Orley Ashenfelter, and David Cards, ed.: Handbook of Labor Economics . vol. 3 (North Holland).

Neff, Thomas J., and Robert L. Heidrick, 2006, Why board service is still attractice, The Corporate Board XXVII, 1-5.

Parrino, Robert, 1997, CEO turnover and outside succession, a cross-sectional analysis, Journal of Financial Economics 46, 165-197.

Perry, Tod, and Urs Peyer, 2005, Board seat accumulation by executives: A shareholder's perspective, The Journal of Finance LX, 2083-2123.

Petersen, Mitchell A., 2007, Estimating standard errors in finance panel data sets: Comparing approaches, Review of Finacial Studies Forthcoming.

PricewaterhouseCoopers, 2001, Non-Executive Directors: A Survey of Practice and Opinion (PricewaterhouseCoopers: London).

Raheja, Charu G., 2005, Determinants of board size and composition: A theory of corporate boards, Journal of Financial and Quantitative Analysis 40, 283-306. 
Rosen, Sherwin, 1982, Authority, control and the distribution of earnings, Bell Journal of Economics $13,311-323$.

Song, Fenghua, and Anjan V. Thakor, 2006, Information control, career concerns, and corporate governance, The Journal of Finance pp. 1845-1896.

Ward, Ralph D., 2003, Saving the Corporate Board-Why Boards Fail and How to Fix Them (John Wiley \& Sons, Inc.: Hoboken, New Jersey).

Weisbach, Michael S., 1988, Outside directors and CEO turnover, Journal of Financial Economics $20,431-460$.

Westphal, James D., and Edward J. Zajac, 1997, Defections from the inner circle: Social exchange, reciprocity, and the diffusion of board independence in U.S. corporations, Administrative Science Quarterly 42, 161-183.

Wintoki, M. Babajide, 2007, Corporate boards and regulation: The effect of the Sarbanes-Oxley Act and the exchange listing requirements on firm value, Journal of Corporate Finance Forthcoming.

Zhou, Xianming, 2001, Understanding the determinants of managerial ownership and the link between ownership and performance: Comment, Journal of Financial Economics 62, 559-571. 


\section{Appendix: Proofs for Propositions}

\section{Proof for Proposition 1}

If the board does not advise the CEO, it will base the replacement decision on the profit realization $\pi=a-C$. Since the board cannot observe $C$ directly, it can only infer the value of $C$ by solving the CEO's maximization problem. Suppose the inferred value is $\hat{C}$. So the board effectively observes $\pi=a-\hat{C}$. The inferred CEO's ability conditional on profit is $a(\pi)=\pi+\hat{C}$. Thus the incumbent CEO is fired if and only if $a(\pi)<a_{0}$ or $\pi<a_{0}-\hat{C}$. And it is trivial to observe that the lower the performance, the more likely the CEO is to be fired.

\section{Proof for Proposition 2}

Since under the advisory scenario the CEO will choose the maximum level of agency cost $\bar{C}$, it is equivalent to proving that under the no-advisory scenario the CEO will choose a level of agency cost lower than this level. The CEO's problem is to maximize $E U_{c}$ by choosing $C$. Since

$$
\begin{aligned}
E U_{c}(C) & =\alpha\left(a_{0}-C\right)+P(\text { CEO not fired }) 2 C \\
& =\alpha\left(a_{0}-C\right)+\left(1-P\left(\pi<a_{0}-\hat{C}\right)\right) 2 C
\end{aligned}
$$

and since $\pi \sim N\left(a_{0}-C, \sigma_{a}^{2}\right)$, CEO maximizes

$$
\begin{aligned}
E U_{c}(C) & =\alpha\left(a_{0}-C\right)+\left(1-P\left(\frac{\pi-a_{0}+C}{\sigma_{a}}<\frac{a_{0}-\hat{C}-a_{0}+C}{\sigma_{a}}\right)\right) 2 C \\
& =\alpha a_{0}+(2-\alpha) C-2 \Phi\left(\frac{C-\hat{C}}{\sigma_{a}}\right) C,
\end{aligned}
$$

where $\Phi($.$) is the CDF of the standard normal distribution. Taking the first derivative of this$ function with respect to $C$, equating the result to zero, and noting that in equilibrium $C=\hat{C}$ one obtains the optimal level of $C$ :

$$
C^{*}=\frac{(1-\alpha) \sigma_{a}}{2 \phi(0)}
$$

One could also easily check the second order condition is satisfied at $C=\hat{C}$. By assumption $C^{*}<\bar{C}$ hence the proposition is established. 


\section{Proof for Proposition 3}

Since under the advisory scenario the CEO will choose the maximum level of $C$ the expected profit is $E \pi_{a}=b_{0}-\bar{C}$, where the subscript $a$ stands for "advisory". Under the no-advisory scenario the expected profit is $E \pi_{n}=a_{0}-C^{*}$, where the subscript $n$ stands for "no-advisory". By comparing $E \pi_{a}$ with $E \pi_{n}$ one obtains that the board should advise the CEO if and only if $b_{0}-a_{0} \geq \bar{C}-C^{*}>0$. 
Table 1: Variable Definitions

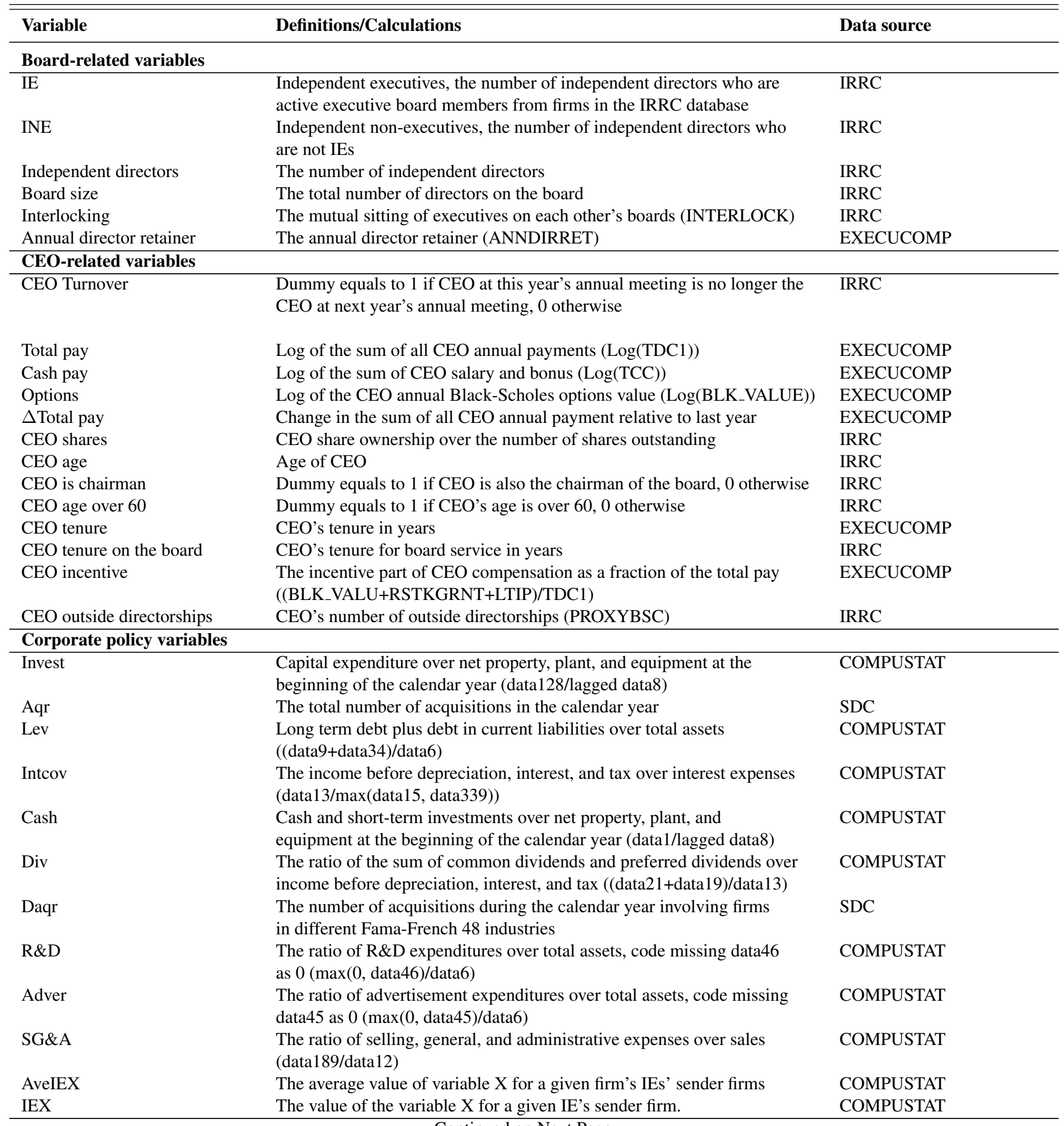
Continued on Next Page... 
Table 1 - Continued

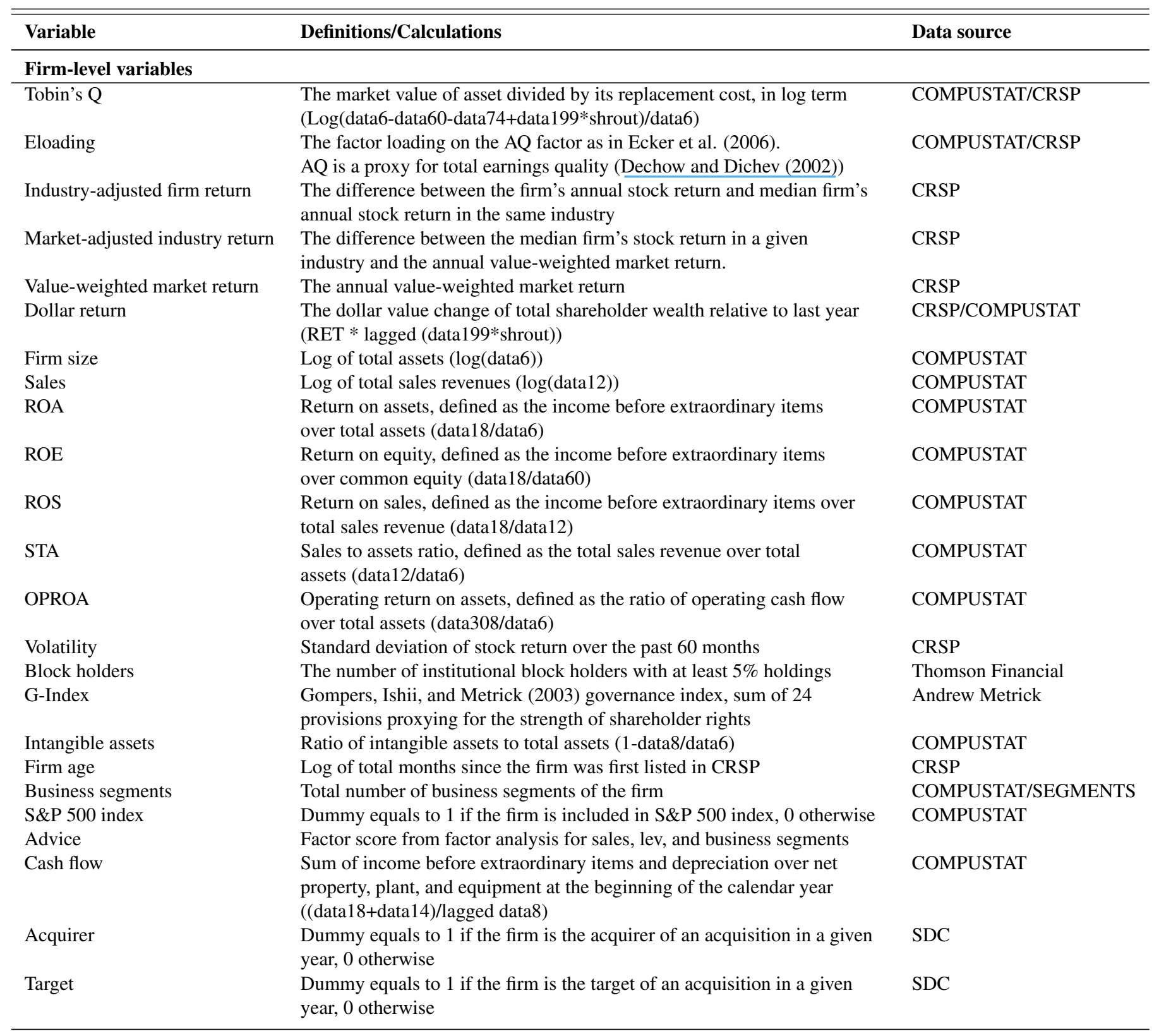




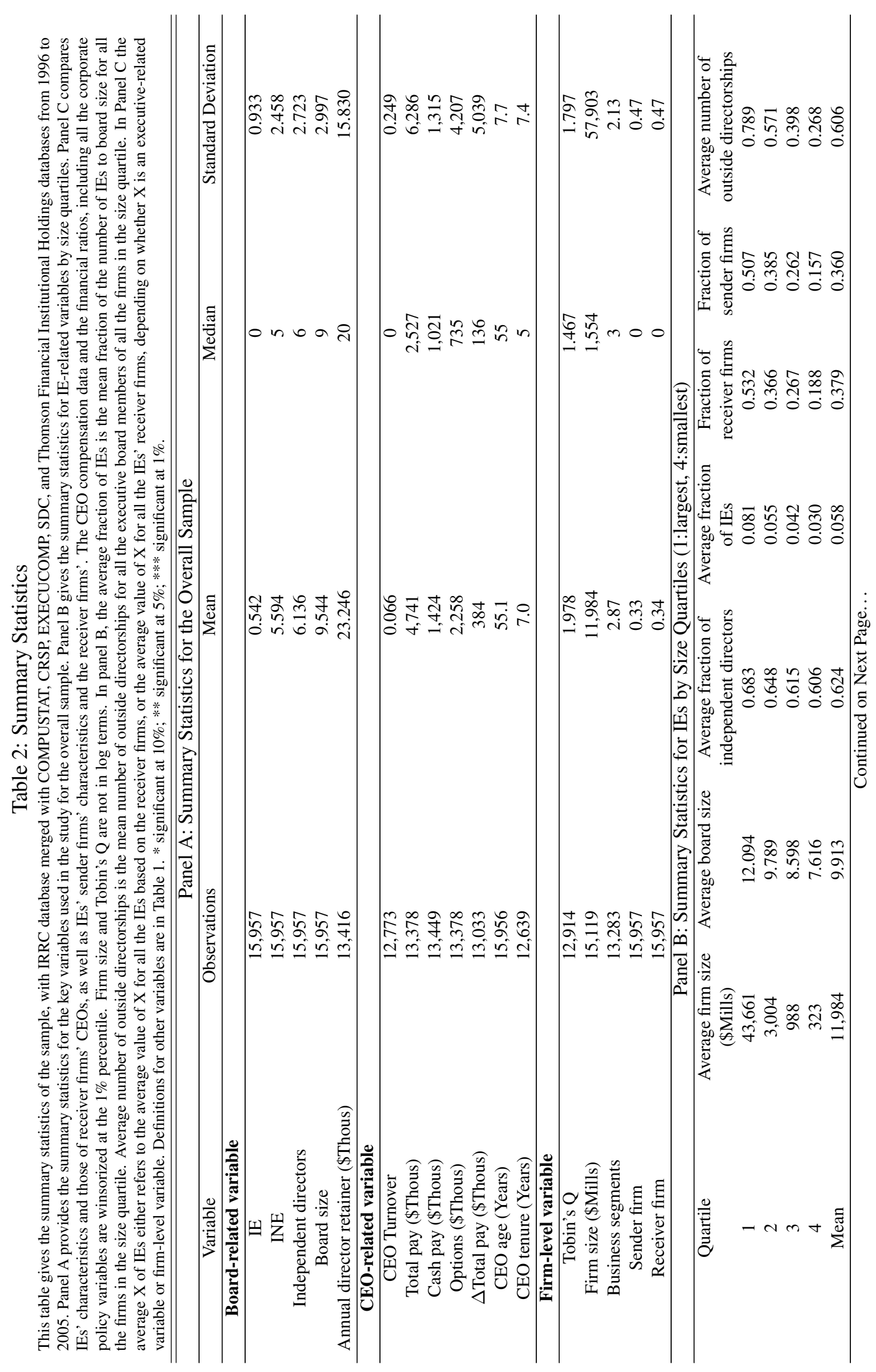




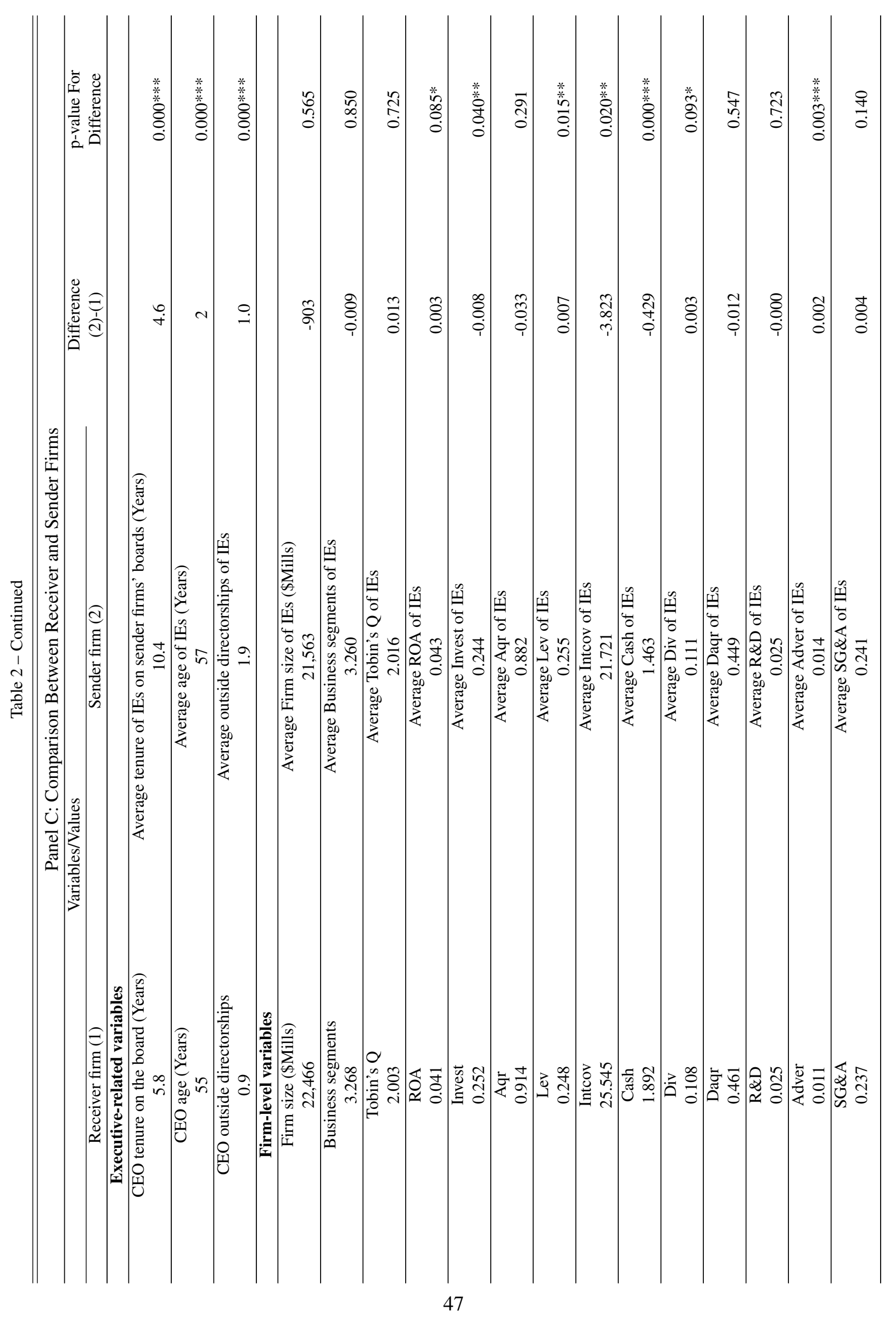




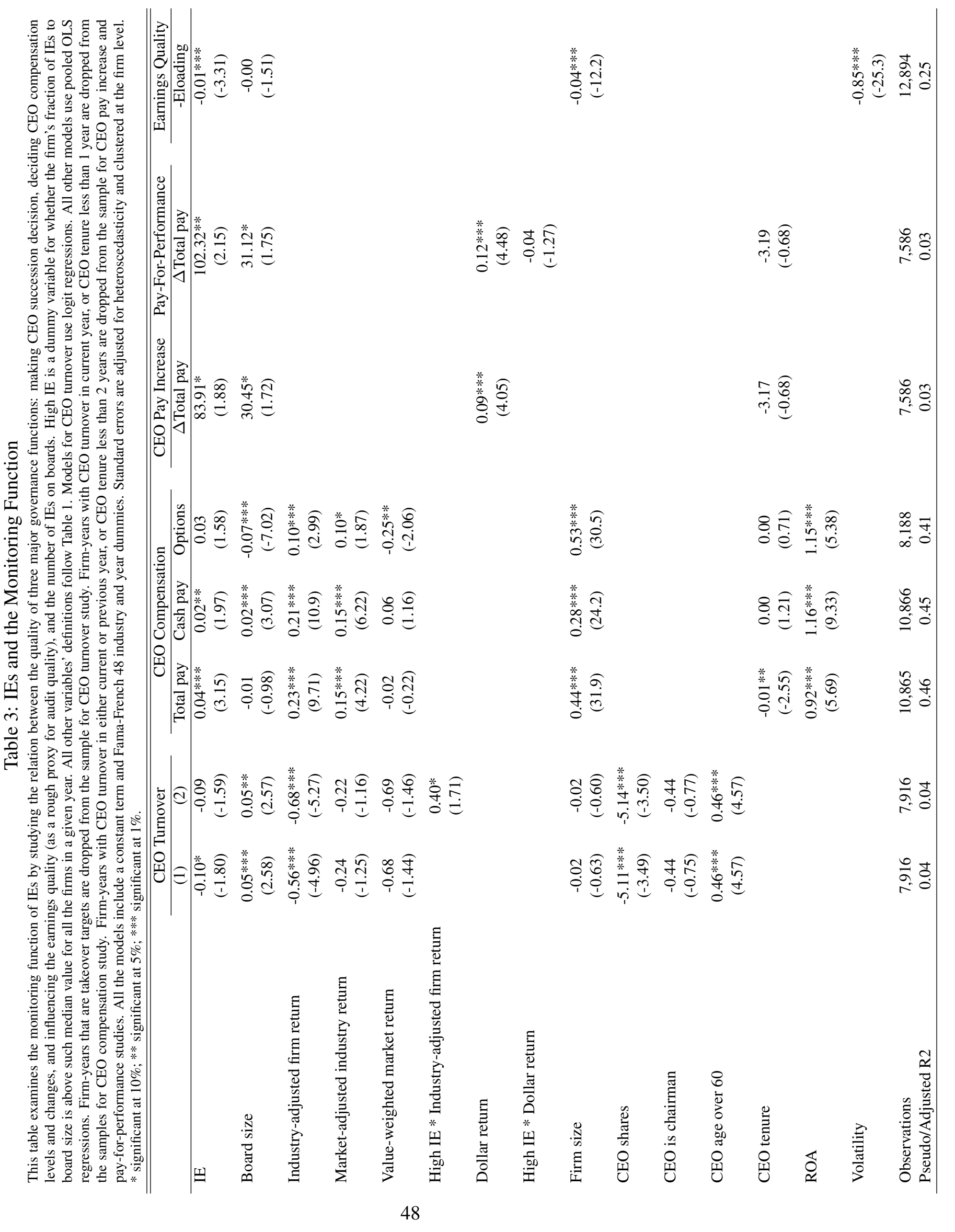




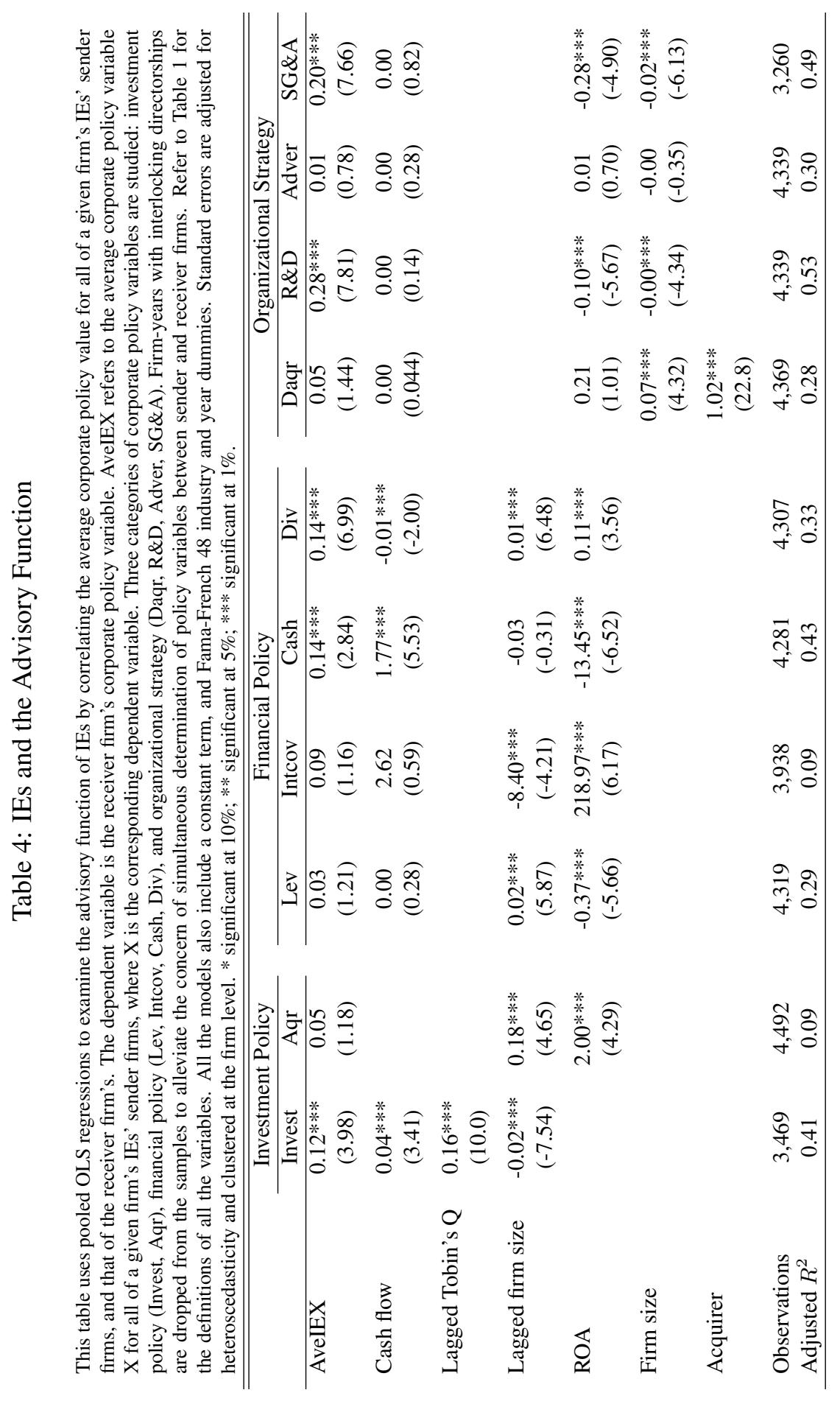




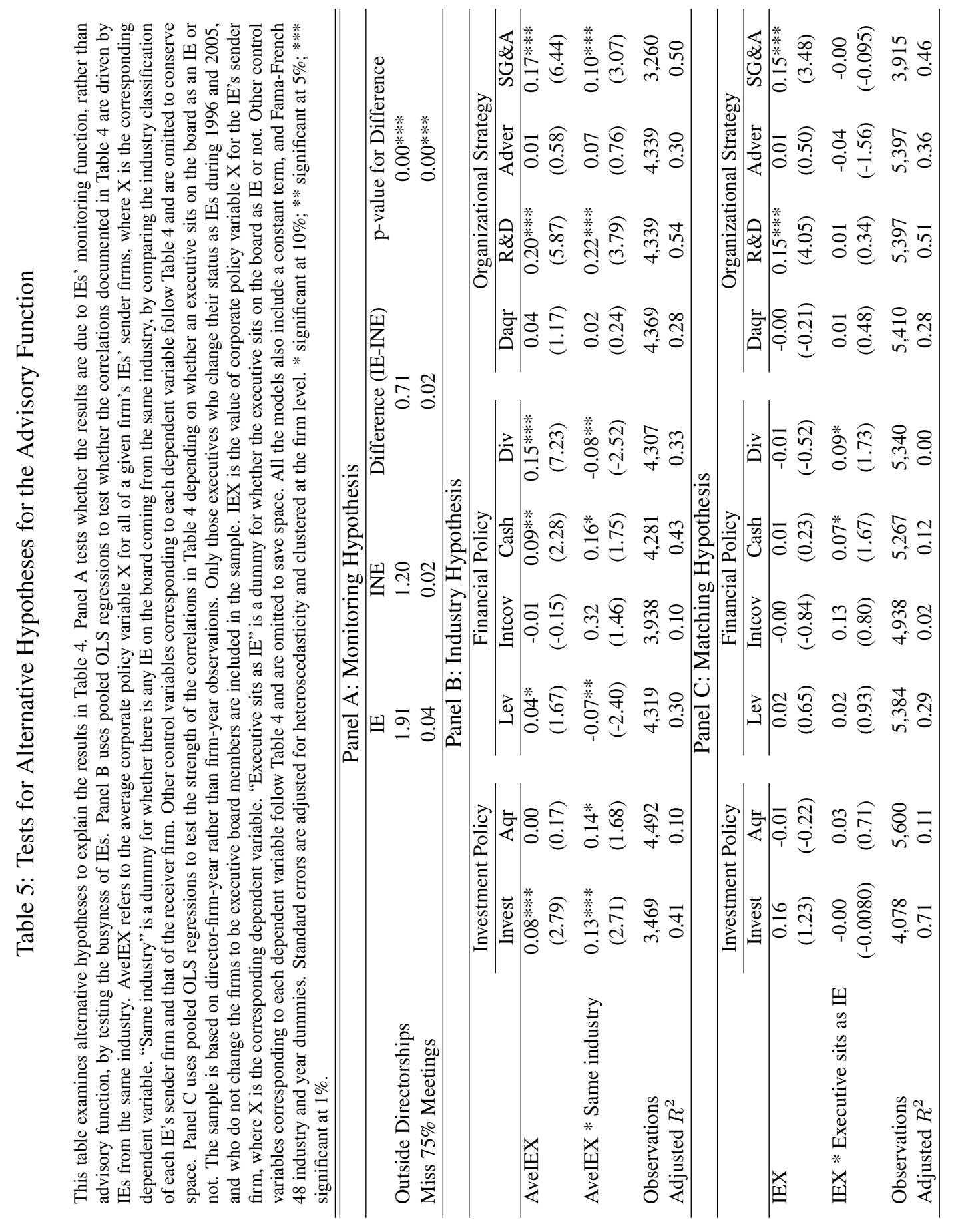




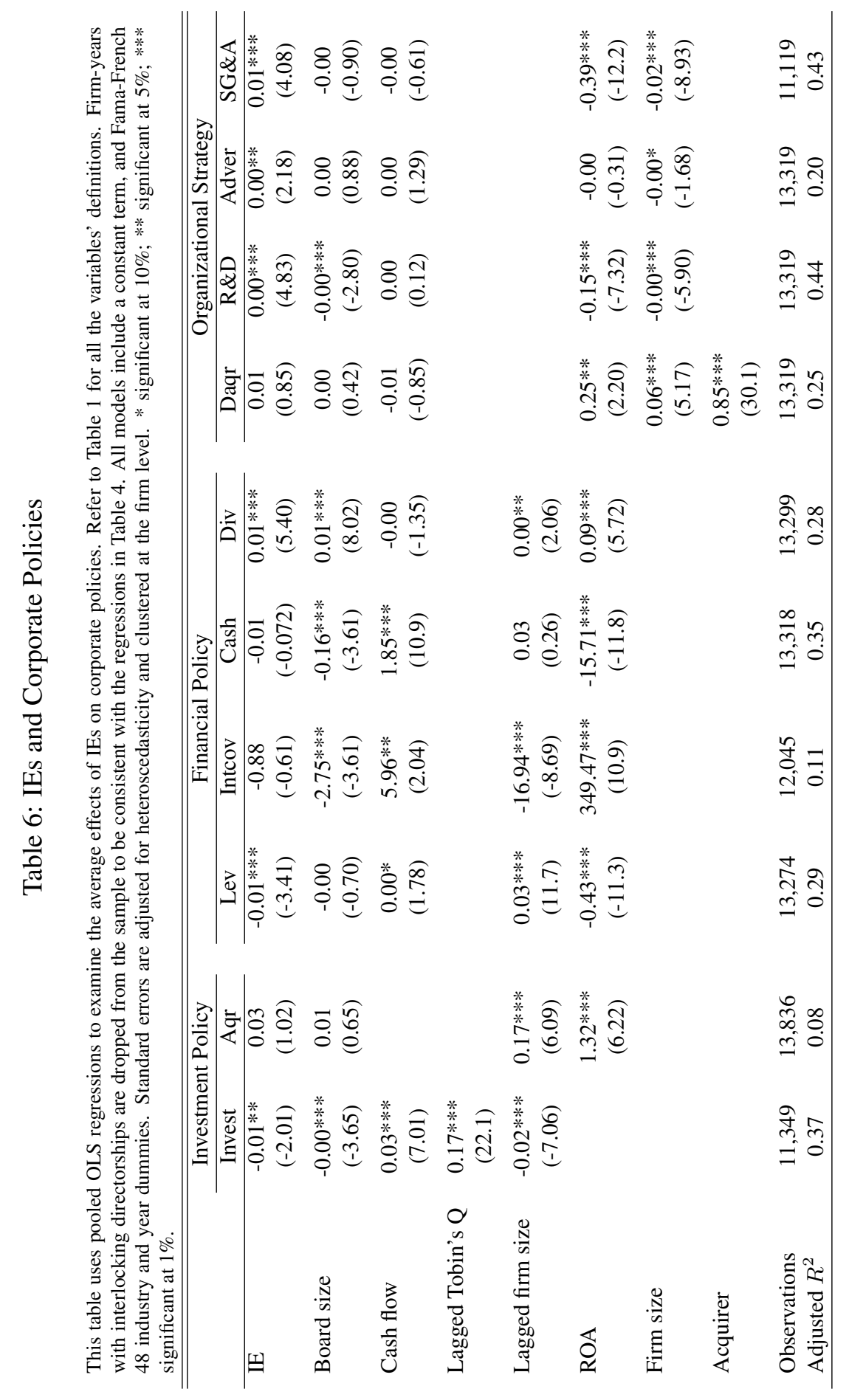


Table 7: IEs and Firm Performance

This table uses pooled OLS to examine the impact of IEs on performance. Dummy(IE_Firm size $>$ Firm size) is a dummy for whether the average size of all the IEs' sender firms is larger than the size of the receiver firm. Refer to Table 1 for all other variables' definitions. All models include a constant term, and Fama-French 48 industry and year dummies. Standard errors are adjusted for heteroscedasticity and clustered at the firm level. * significant at $10 \%$; ** significant at $5 \%$; *** significant at $1 \%$.

\begin{tabular}{|c|c|c|c|}
\hline & \multicolumn{3}{|c|}{ Tobin's Q } \\
\hline & (1) & (2) & (3) \\
\hline IE & $\begin{array}{c}0.024 * * * \\
(3.27)\end{array}$ & $\begin{array}{c}0.020^{* *} \\
(2.46)\end{array}$ & $\begin{array}{l}0.001 \\
(0.11)\end{array}$ \\
\hline Lev & $\begin{array}{c}-0.140 * * \\
(-2.43)\end{array}$ & $\begin{array}{l}-0.092 \\
(-1.42)\end{array}$ & $\begin{array}{l}-0.127 \\
(-1.33)\end{array}$ \\
\hline $\mathrm{R} \& \mathrm{D}$ & $\begin{array}{c}2.426^{* * * *} \\
(10.6)\end{array}$ & $\begin{array}{c}1.963 * * * \\
(8.64)\end{array}$ & $\begin{array}{c}2.353 * * * \\
(5.02)\end{array}$ \\
\hline Invest & $\begin{array}{c}0.355^{* * * *} \\
(10.2)\end{array}$ & $\begin{array}{c}0.379 * * * \\
(10.0)\end{array}$ & $\begin{array}{c}0.330 * * * \\
(4.51)\end{array}$ \\
\hline Div & & $\begin{array}{c}0.245^{* * * *} \\
(2.88)\end{array}$ & $\begin{array}{l}0.178 \\
(1.25)\end{array}$ \\
\hline Adver & & $\begin{array}{c}0.497 * \\
(1.73)\end{array}$ & $\begin{array}{l}0.301 \\
(0.77)\end{array}$ \\
\hline SG\&A & & $\begin{array}{c}0.233 * * * \\
(2.98)\end{array}$ & $\begin{array}{c}0.468 * * * \\
(3.19)\end{array}$ \\
\hline Dummy(IE_Firm size $>$ Firm size $) *$ IE & & & $\begin{array}{c}0.023 * * \\
(2.16)\end{array}$ \\
\hline Board size & $\begin{array}{l}-0.004 \\
(-1.20)\end{array}$ & $\begin{array}{l}-0.005 \\
(-1.25)\end{array}$ & $\begin{array}{l}0.005 \\
(0.93)\end{array}$ \\
\hline ROA & $\begin{array}{c}2.121 * * * \\
(16.9)\end{array}$ & $\begin{array}{c}2.082 * * * \\
(16.7)\end{array}$ & $\begin{array}{c}2.209 * * * \\
(10.5)\end{array}$ \\
\hline Block holders & $\begin{array}{c}-0.050 * * * \\
(-11.6)\end{array}$ & $\begin{array}{c}-0.051 * * * \\
(-11.0)\end{array}$ & $\begin{array}{c}-0.042 * * * \\
(-5.84)\end{array}$ \\
\hline G-Index & $\begin{array}{c}-0.005 * \\
(-1.81)\end{array}$ & $\begin{array}{c}-0.006 * \\
(-1.95)\end{array}$ & $\begin{array}{l}-0.007 \\
(-1.64)\end{array}$ \\
\hline CEO incentive & $\begin{array}{c}0.169 * * * \\
(7.51)\end{array}$ & $\begin{array}{c}0.166^{* * * *} \\
(6.99)\end{array}$ & $\begin{array}{c}0.145^{* * * *} \\
(3.82)\end{array}$ \\
\hline Firm size & $\begin{array}{c}-0.064 * * * \\
(-7.30)\end{array}$ & $\begin{array}{c}-0.044 * * * \\
(-4.52)\end{array}$ & $\begin{array}{c}-0.030 * * \\
(-2.20)\end{array}$ \\
\hline Intangible assets & $\begin{array}{l}0.015 \\
(0.27)\end{array}$ & $\begin{array}{c}-0.003 \\
(-0.054)\end{array}$ & $\begin{array}{l}-0.035 \\
(-0.39)\end{array}$ \\
\hline Firm age & $\begin{array}{c}-0.025 * * * \\
(-2.58)\end{array}$ & $\begin{array}{c}-0.037 * * * \\
(-3.54)\end{array}$ & $\begin{array}{c}-0.024 * \\
(-1.70)\end{array}$ \\
\hline Business segments & $\begin{array}{c}-0.011 * * * \\
(-3.24)\end{array}$ & $\begin{array}{c}-0.015 * * * \\
(-4.11)\end{array}$ & $\begin{array}{c}-0.013 * * \\
(-2.55)\end{array}$ \\
\hline S\&P 500 index & $\begin{array}{c}0.268 * * * \\
(11.8)\end{array}$ & $\begin{array}{c}0.292 * * * \\
(11.2)\end{array}$ & $\begin{array}{c}0.233 * * * \\
(7.09)\end{array}$ \\
\hline Observations & 9,263 & 7,677 & 2,563 \\
\hline Adjusted $R^{2}$ & 0.52 & 0.51 & 0.56 \\
\hline
\end{tabular}


Table 8: Explaining the Significant Relation between IEs and Firm Performance

This table uses the post-SOX environment to test the hypothesis that the scarcity of IEs drives their significant relation with firm performance. Panel A tests the difference between the change of director compensation for firms increasing the number of IEs $(\Delta I E>0)$ versus firms decreasing the number of IEs $(\Delta I E<0)$ over 2002 and 2005. The sample is based on matching these two groups of firms by industry and size. Panel B examines the change of the number of outside directorships for executives post-SOX across the size quartiles (largest Quartile 1 vs. smallest Quartile 4). Panel C examines the changing demographics of IEs post-SOX compared with pre-SOX. Firm size is the total assets and is not in log term. Average size of IEs' sender firms refers to the mean of the average size of all the IEs' sender firms. Panel D tests the scarcity hypothesis formally by running pooled OLS regressions over the sample from 1996 to 2005. Dummy(IE_Firm size>Firm size) is a dummy for whether the average size of all the IEs' sender firms is larger than the receiver firm's size. SOXyear is a dummy for whether the year is after 2002, the year when SOX was enacted. Other control variables follow Model 3 in Table 7 and are omitted to conserve space. Standard errors are adjusted for heteroscedasticity and clustered at the firm level. * significant at $10 \%$; ** significant at 5\%; *** significant at $1 \%$.

\begin{tabular}{|c|c|c|c|c|}
\hline \multicolumn{5}{|c|}{ Panel A: T-test for the Change of Director Compensation for $\Delta I E<0$ vs $\Delta I E>0$ Between 2002 and 2005} \\
\hline & $\Delta I E<0$ & $\Delta I E>0$ & \multicolumn{2}{|l|}{ p-value for Difference } \\
\hline$\Delta$ Annual Director Retainer (\$) & 9035.21 & 14572.79 & \multirow[t]{2}{*}{$0.02 * *$} & \\
\hline Observations & 62 & 63 & & \\
\hline \multicolumn{5}{|c|}{ Panel B: Changing Number of Outside Directorships Post-SOX for Executives by Size Quartiles } \\
\hline & Mean & Quartile 1 & Quartile 4 & \\
\hline Before SOX & 0.52 & 0.81 & 0.27 & \\
\hline After SOX & 0.50 & 0.75 & 0.27 & \\
\hline Difference & 0.02 & -0.06 & -0.00 & \\
\hline $\mathrm{p}$-value for Difference & 0.16 & $0.05 * *$ & 0.98 & \\
\hline \multicolumn{5}{|c|}{ Panel C: Changing Demographics of IEs Post-SOX } \\
\hline & $\begin{array}{l}\text { Firm size } \\
(\$ \text { Mills) (1) }\end{array}$ & $\begin{array}{c}\text { Average size of IEs' } \\
\text { sender firms (\$Mills) (2) }\end{array}$ & $\begin{array}{l}\text { Difference } \\
(2)-(1)\end{array}$ & $\begin{array}{c}\mathrm{p} \text {-value } \\
\text { for Difference }\end{array}$ \\
\hline Before SOX & 18196.64 & 20423.12 & 2226.48 & 0.13 \\
\hline After SOX & 35387.06 & 25013.24 & -10373.82 & $0.02 * *$ \\
\hline \multicolumn{5}{|c|}{ Panel D: Test for the Scarcity of IEs } \\
\hline \multicolumn{5}{|c|}{ Tobin's Q } \\
\hline IE & \multicolumn{4}{|c|}{$\begin{array}{c}-0.00 \\
(-0.21)\end{array}$} \\
\hline Dummy(IE_Firm size $>$ Firm size $) *$ IE & \multicolumn{4}{|c|}{$\begin{array}{c}0.02 \\
(1.52)\end{array}$} \\
\hline Dummy(IE_Firm size $>$ Firm size $) *$ IE $*$ SOXyear & \multicolumn{4}{|c|}{$\begin{array}{c}0.04 * * \\
(2.14)\end{array}$} \\
\hline Observations & \multicolumn{4}{|c|}{2,564} \\
\hline Adjusted $R^{2}$ & \multicolumn{4}{|c|}{0.57} \\
\hline
\end{tabular}


Table 9: IEs and Firm's Demand for Advice

This table examines the relation between the firm's demand for advice and the number of IEs on boards. It also examines whether IEs are more valuable when firm's advising demand is higher, and the simultaneous determination of IEs and firm performance. Advice dummy is a dummy for whether the firm's Advice is greater than the median value of this variable for all the firms in a given year. Refer to Table 1 for all the variables' definitions. Other control variables for Tobin's Q follow Model 3 in Table 7 and are omitted to conserve space. All models include a constant term, and Fama-French 48 industry and year dummies. Standard errors for the pooled OLS regressions are adjusted for heteroscedasticity and clustered at the firm level. * significant at $10 \%$; ** significant at 5\%; *** significant at $1 \%$.

\begin{tabular}{|c|c|c|c|c|}
\hline & \multicolumn{2}{|c|}{ Pooled OLS } & \multicolumn{2}{|c|}{ 3SLS } \\
\hline & IE & Tobin's Q & IE & Tobin's Q \\
\hline Advice & $\begin{array}{c}0.27 * * * \\
(9.96)\end{array}$ & & $\begin{array}{c}0.29 * * * \\
(17.7)\end{array}$ & \\
\hline IE & & $\begin{array}{c}-0.00 \\
(-0.18)\end{array}$ & & $\begin{array}{c}0.34 * * * \\
(7.22)\end{array}$ \\
\hline IE * Advice dummy & & $\begin{array}{c}0.03 * * \\
(2.13)\end{array}$ & & \\
\hline Tobin's Q & $\begin{array}{c}0.10 * * * \\
(3.26)\end{array}$ & & $\begin{array}{c}0.39 * * * \\
(7.42)\end{array}$ & \\
\hline Board size & $\begin{array}{c}0.05 * * * \\
(5.97)\end{array}$ & $\begin{array}{c}-0.00 \\
(-1.27)\end{array}$ & $\begin{array}{c}0.05^{* * *} * \\
(9.81)\end{array}$ & $\begin{array}{c}-0.02 * * * \\
(-5.94)\end{array}$ \\
\hline ROA & $\begin{array}{c}-0.04 \\
(-0.37)\end{array}$ & $\begin{array}{c}2.08 * * * \\
(16.7)\end{array}$ & $\begin{array}{c}-0.75 * * * \\
(-4.62)\end{array}$ & $\begin{array}{c}2.06 * * * \\
(35.9)\end{array}$ \\
\hline$R \& D$ & $\begin{array}{c}0.68 * * * \\
(2.67)\end{array}$ & $\begin{array}{c}1.96 * * * \\
(8.62)\end{array}$ & $\begin{array}{c}-0.20 \\
(-0.70)\end{array}$ & $\begin{array}{c}1.74 * * * \\
(12.4)\end{array}$ \\
\hline G-Index & $\begin{array}{c}0.03 * * * \\
(4.33)\end{array}$ & $\begin{array}{l}-0.01 * \\
(-1.93)\end{array}$ & $\begin{array}{c}0.03 * * * \\
(7.98)\end{array}$ & $\begin{array}{c}-0.02 * * * \\
(-6.29)\end{array}$ \\
\hline CEO tenure & $\begin{array}{c}-0.01 * * * \\
(-5.67)\end{array}$ & & $\begin{array}{c}-0.00 * * * \\
(-3.78)\end{array}$ & \\
\hline CEO age & $\begin{array}{c}-0.00 * * * \\
(-2.58)\end{array}$ & & $\begin{array}{c}-0.00 * * * \\
(-3.43)\end{array}$ & \\
\hline Firm age & $\begin{array}{c}0.14 * * * \\
(6.15)\end{array}$ & $\begin{array}{c}-0.04 * * * \\
(-3.62)\end{array}$ & $\begin{array}{c}0.15 * * * \\
(11.5)\end{array}$ & $\begin{array}{c}-0.08 * * * \\
(-8.39)\end{array}$ \\
\hline Intangible assets & $\begin{array}{c}-0.10 \\
(-0.89)\end{array}$ & $\begin{array}{c}-0.00 \\
(-0.056)\end{array}$ & $\begin{array}{l}-0.06 \\
(-0.91)\end{array}$ & $\begin{array}{c}0.01 \\
(0.30)\end{array}$ \\
\hline $\begin{array}{l}\text { Observations } \\
\text { Adjusted } R^{2}\end{array}$ & $\begin{array}{c}9,393 \\
0.23\end{array}$ & $\begin{array}{c}7,677 \\
0.51\end{array}$ & $\begin{array}{c}7,361 \\
0.23\end{array}$ & $\begin{array}{c}7,361 \\
0.29\end{array}$ \\
\hline
\end{tabular}




\section{Table 10: Robustness of the Relation Between IEs and Firm Performance}

This table examines the robustness of the positive relation between IEs and firm performance. Model $1 \& 2$ use pooled OLS to run regressions for Tobin's Q. Other control variables follow Model 2 in Table 7 and are omitted to conserve space. The models also include a constant term, and Fama-French 48 industry and year dummies. Standard errors are adjusted for heteroscedasticity and clustered at the firm level. Model $3 \& 4$ use OLS to regress the change of Tobin's Q on the change of IE over two three-year intervals, from 2002 to 2005 (post-SOX) and from 1999 to 2002 (pre-SOX), respectively. To increase the power of the test firms without any change for the number of IEs are dropped from the samples. Model $3 \& 4$ also include two other control variables: the change of board size and the change of firm size over the three-year intervals and are omitted to conserve space. They also control for a constant term and Fama-French 48 industry dummies. Standard errors are adjusted for heteroscedasticity. * significant at $10 \%$; ** significant at $5 \%$; *** significant at $1 \%$.

\begin{tabular}{|c|c|c|c|c|}
\hline & \multicolumn{2}{|c|}{ Tobin's Q } & \multicolumn{2}{|c|}{$\Delta$ Tobin's $\mathrm{Q}$} \\
\hline & (1) & (2) & (3) & (4) \\
\hline & & & $2002-2005$ & $1999-2002$ \\
\hline IE & & $\begin{array}{c}0.011 * * * \\
(2.75)\end{array}$ & & \\
\hline Board size & & $\begin{array}{l}-0.000 \\
(-0.25)\end{array}$ & & \\
\hline Lagged IE & $\begin{array}{c}0.014 * \\
(1.69)\end{array}$ & & & \\
\hline Lagged board size & $\begin{array}{c}-0.007 * \\
(-1.81)\end{array}$ & & & \\
\hline Lagged Tobin's Q & & $\begin{array}{c}0.653 * * * \\
(46.0)\end{array}$ & & \\
\hline$\Delta \mathrm{IE}$ & & & $\begin{array}{l}0.03 * \\
(1.67)\end{array}$ & $\begin{array}{c}0.00 \\
(0.14)\end{array}$ \\
\hline Observations & 6,630 & 7,565 & 210 & 219 \\
\hline Adjusted $R^{2}$ & 0.52 & 0.73 & 0.12 & 0.08 \\
\hline
\end{tabular}




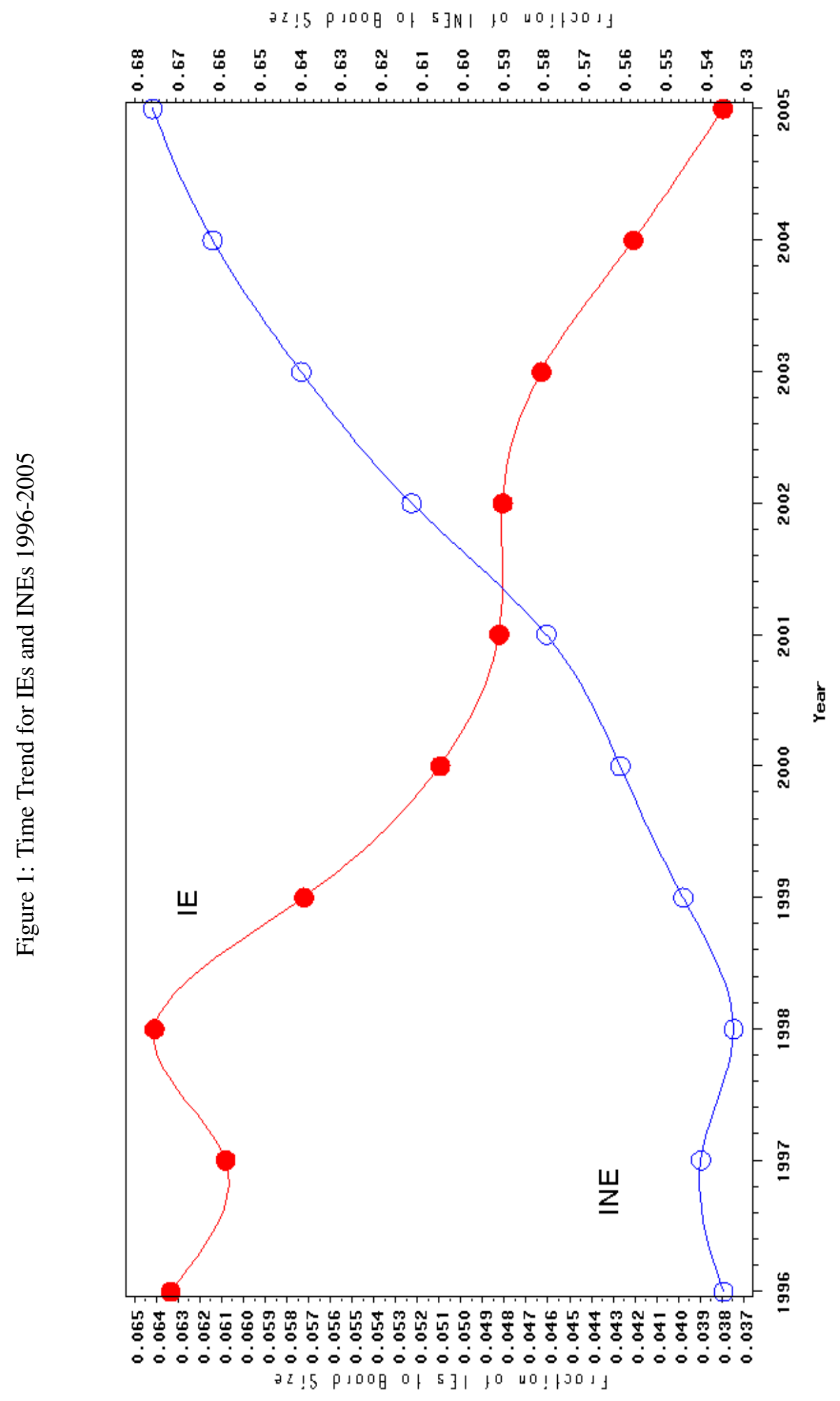

